\title{
DATA MANAGEMENT TECHNIQUES FOR BLADE VIBRATION ANALYSIS
}

\section{TECHNIKI ZARZĄDZANIA DANYMI W ANALIZIE DRGAŃ LOPATEK}

\author{
Radosław Przysowa ${ }^{1}$, Aleksander Tuzik ${ }^{2}$ \\ ${ }^{1)}$ Instytut Techniczny Wojsk Lotniczych, ${ }^{2)}$ Politechnika Wrocławska \\ radoslaw.przysowa@itwl.pl,aleksander.tuzik@gmail.com
}

\begin{abstract}
Well-designed procedures are required to handle large amounts of data, generated by complex measurement systems used in engine tests. The paper presents selected methodologies and software tools for characterisation and monitoring of blade vibration. Common file formats and data structures as well as methods to process and visualise tip-timing data are discussed. Report Generation Framework (RGF) developed in Python is demonstrated as a flexible tool for processing and publishing blade vibration results.
\end{abstract}

Keywords: blade vibration, tip-timing, report generation, Python, Matlab

Streszczenie: Dobrze zaprojektowane procedury sa wymagane do obstugi dużych ilości danych generowanych przez złożone systemy pomiarowe stosowane $w$ testach silników lotniczych. $W$ artykule przedstawiono wybrane metody $i$ narzędzia programowe stużace do pomiarów i monitorowania drgań topatek. Omówiono stosowane formaty plików $i$ struktury danych, jak również sposoby przetwarzania $i$ wizualizacji danych pomiarowych. Przedstawiono biblioteke RGF, opracowana w języku Python, która jest elastycznym narzędziem do przetwarzania i publikowania wyników drgań topatek.

Stowa kluczowe: drgania topatek, metoda dyskretno-fazowa, generowanie raportów, Python, Matlab 
Data management techniques for blade vibration analysis

Techniki zarzadzania danymi w analizie drgań topatek

\section{DATA MANAGEMENT TECHNIQUES FOR BLADE VIBRATION ANALYSIS}

\section{Introduction}

Experimental tests of engines are usually planned in details and the observed parameters are defined, but very often happens that too little attention is paid to the preparation for collection and processing of measurement data. The best situation is when tools for determination of needed parameters are ready before tests and are able to operate on-line. The off-line analysis of data usually takes more time than it is primarily expected, since a definite workload is connected with the access to data. It often happens that data is not stored in one place, it has insufficient metadata, different formats or is recorded in a different function of time. Engineers are overwhelmed with data and usually are able to analyse only a few percent of available records.

The non-contact blade vibration measurement is performed during engine development to verify design quality of bladed disk and its structural integrity and is the primary tool for mitigation of High Cycle Fatigue risk.

Current engine development programmes involve thousands hours of testing, including core-engines' and full-scale tests of different types. Preparation of the instrumentation is an extremely laborious and costly process involving sensor routing, labelling and management of sensor location information.

The way of collecting, documenting, processing and archiving of measurement data should be designed simultaneously to the measuring instrumentation. In the blade tip-timing (BTT), we deal with high sensitivity of obtained analysis results to the number and distribution of sensors and that is why information about changes in configuration has to be tracked and available by reviewing the data.

The measurement and analysis of blade vibration should provide:

- Vibration parameters of individual blades such as frequency, amplitude and phase in function of rotational speed (Campbell diagram);

- Characterisation of bladed disk vibration - nodal diameter, frequency, amplitude and phase;

- Identification of resonances - related vibration mode, speed and engine order (EO);

- Indication of the blades, which differ from the baseline e.g. high responding blades.

Similarly to other measuring systems in a test-cell, the level and trend of blade vibration have to be automatically monitored during test-cell experiments (sentry feature). In case of a damage risk, alarms are risen or even engine is shut down. The participation of an engineer, which observes the blade response during the testrun is still necessary in product development, certification and investigation of failures. 


\section{Data Management}

Engine testing requires advanced methodologies for processing of large datasets and managing measurement configuration. In this section we review best practices of handling blade vibration data including storage, documenting, data mining, visualisation and reporting.

\section{Tip-timing system}

The Blade Tip Timing system is part of a large measurement installation operated in a test cell [5]. Its structure is similar to dynamic signal acquisition (DSA) systems often used simultaneously to analyses of strain gauges, unsteady pressure or casing vibration. They comprise a modular industrial computer connected to Gigabit Network based on Windows or Linux and are mounted in a rack together with sensor interfaces (data acquisition modules and conditioning units). The microsecond time synchronisation (IRIG B, Inter-Range Instrumentation Group) is usually used to be able to compare BTT results with other dynamic signals.

File servers such as local RAID matrix or Network Attached Storage (NAS) are used to handle incoming data and provide access to previous tests. Test results can be shared through local network or even a corporate Intranet. Their copies are often sent by courier to other locations on hard drives or a flash memory. Data backups are stored on external hard disks or magnetic tapes.

A few turnkey BTT systems (usually custom-made) and some supporting software tools are available on the market [6]-[13]. Alternatively, an acquisition system can be built internally with the use of commercially available components (Fig. 1) [4].

A BTT software suite typically consists of two major packages:

- Online part, including acquire, real time analysis \& replay,

- Offline Analysis.

Some supplementary tools such as blade vibration simulator, probe placement optimisation are usually provided.

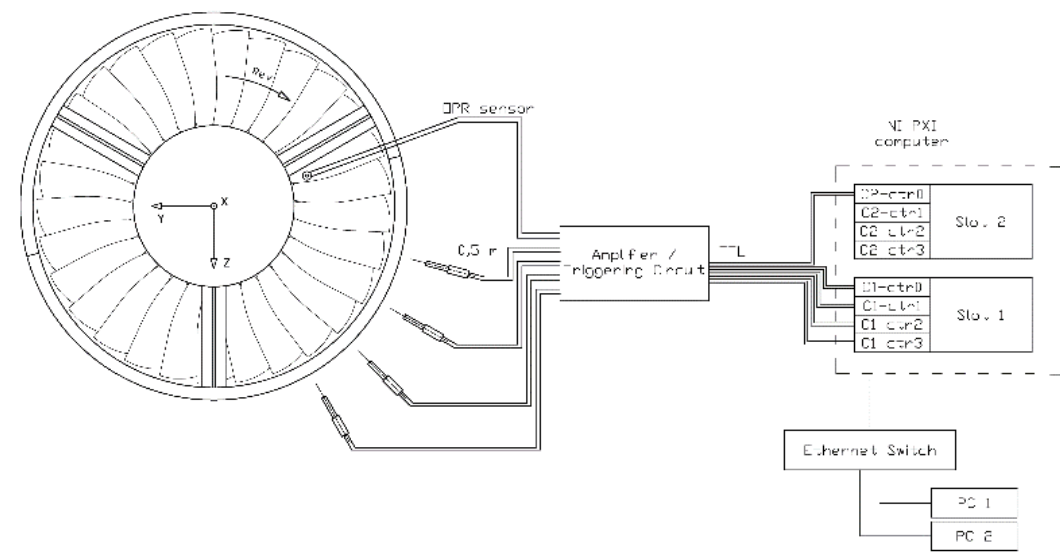

Fig. 1. Tip-timing acquisition system developed at ITWL, based on NI PXI computer 
Data management techniques for blade vibration analysis

Techniki zarzadzania danymi w analizie drgań topatek

The first package can usually work both in Real Time and Replay mode offering similar functionality, including on-line vibration estimation (Least Squares Sine Fit), statistical data reduction and spectral transforms, to be presented as plots (waterfall, individual and all-blade spectrum), tables and exported in popular formats. You can also define how data is stored and select data for further analysis in the off-line package. Each stage of a rotor is often monitored by a separate subsystem and operator.

The Off-line Analysis package is focused to deliver quantitative vibration parameters in form of tables as a result of fitting TOA data to the oscillator model and evaluation of spectral transforms. However, their visualisation is also needed, so that an engineer may be able to assess and select the most important results. To start an automated vibration estimation, an operator needs to define parameters (ranges of speeds, EO, type of an analysis).

\section{Measurement data format}

In the standard tip-timing method only one datum (referred as Time of Arrival) is gathered per sensor in one rotation. TOA data are stored in form of a timestamp of digital counter (unsigned 32-bit integer) or alternatively as time in seconds in double precision floating point format $(64 \mathrm{bit})$. Although blade vibration are undersampled in BTT, a considerable bitrate as large as 100-200 kbyte/s per channel have to be handled by the data acquisition system. Data from sensors may in some conditions come in a different rate, thus it is usually recorded in separate files. One-per-rev or reference sensor is stored in the last or the first file.

TOA values from each sensor are recorded in a separate binary file, which includes a sequence of floating point arrival times or integer counter readings (table 1). Sometimes results of primary data reduction (average amplitude, stack diagram, frequency estimates) are also simultaneously stored.

After pre-processing of raw TOA data we obtain intermediate or sorted files, in which sensor indications are assigned to particular blades (table 2). It is possible to store data directly in form of aligned matrices of sensor results (sorted files), however in this structure we cannot record signals of poor quality, in which extra or surplus blades occur.

Pre-processed sorted data is a start point for performing spectrum transformation and vibration estimation. Further analysis require prior knowledge about vibration modes and resonances to be able to fit data to the oscillator model [2]. Final results are collectively presented in form of frequency and amplitude estimates on the Campbell diagram, on which structural engineers can further work. 
Table 1. Examples of folder structure and file naming convention

\begin{tabular}{|c|c|c|c|c|}
\hline & $\begin{array}{c}\text { Rolls-Royce } \\
\text { BTT }\end{array}$ & Hood Tech & ITWL & ITWL counters \\
\hline folder name & Shot001 & 02oct2008 & $\begin{array}{c}2015-05-20 \\
/ 10-42-27\end{array}$ & $\begin{array}{c}2014-08-09 \\
\text { /22-46-15 }\end{array}$ \\
\hline raw TOA data & Shot001.001 & SDFG_1.001 & X1-ai0.tdx & C1-ctr1.u32 \\
& Shot001.002 & SDF__1.002 & $\begin{array}{c}\text { X1-ai1.tdx } \\
\text { C1-ctr2.u32 }\end{array}$ \\
& Shot001.003 & SDFG_1.003 & X1-ai2.tdx & C1-ctr3.u32 \\
& Shot001.004 & SDFG_1.004 & X1-ai3.tdx & C1-ctr4.u32 \\
& Shot001.005 & SDFG_1.005 & X1-ai4.tdx & C1-ctr5.u32 \\
& Shot001.006 & SDFG_1.006 & X1-ai5.tdx & C1-ctr6.u32 \\
& Shot001.007 & & X1-ai6.tdx & \\
& Shot001.008 & & X1-ai7.tdx & \\
\hline one/rev & Shot001.009 & SDFG_1.007 & X1-ai8.tdx & C1-ctr0.u32 \\
\hline file format & double & unsigned int32 & double & unsigned int32 \\
\hline byte order & Intel & Motorola & Intel & Intel \\
\hline configuration & config.cfg & SDFG_1.inf & X1.dat (text) & C1.dat (text) \\
& (binary) & (text) & & \\
\hline
\end{tabular}

The acquisition encompasses the whole time of engine work, however data is usually recorded in fragments that reflect performed manoeuvres. A next dataset (shot) is created when idling speed is reached (with some hysteresis), so it includes a single LCF cycle i.e. transition of rotational speed from idling to take-off speed and back (Fig. 2). The dataset is usually stored in a separate folder with an autoincreased shot counter in the name. Alternatively, the acquisition time can be used as a unique folder name.

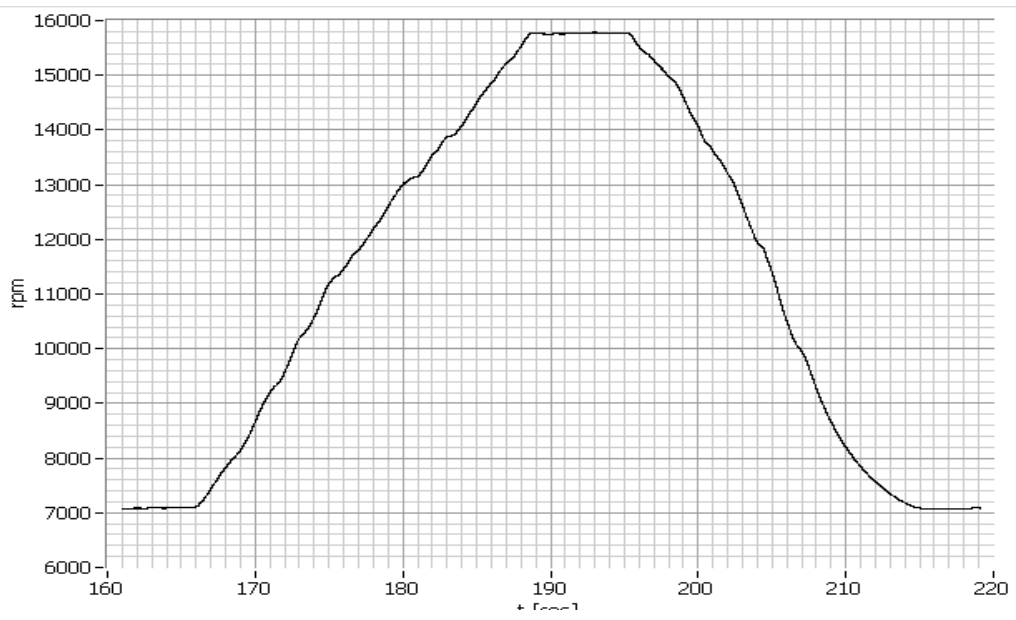

Fig. 2. LCF cycle - sweeping rotational speed from idling to take-off and back 
Data management techniques for blade vibration analysis Techniki zarzadzania danymi w analizie drgań topatek

Analysis results are typically not stored in one catalogue with measurement data, instead a subfolder or a parallel tree of catalogues in other localisation is created. Successive analysis trials should not overwrite previous ones, so unique names of folders are used with time or number in the name.

As different formats and file naming conventions are used, you cannot analyse blade vibration with the use of another package without the burden of converting files. There is uncompleted activity to agree a common data format [1] to be able to exchange files in cooperative tests.

Table 2. Example of alignment (sorting) of raw TOA data

\begin{tabular}{|c|c|c|c|}
\hline OPR & $\begin{array}{l}\text { sensor } \\
1\end{array}$ & $\begin{array}{l}\text { sensor } \\
2\end{array}$ & $\begin{array}{l}\text { sensor } \\
\mathrm{n}\end{array}$ \\
\hline $\mathrm{t}_{10}$ & $\mathrm{t}_{11}$ & $\mathrm{t}_{\mathrm{m} 2}$ & $\mathrm{t}_{\mathrm{m}-1, \mathrm{n}}$ \\
\hline$t_{20}$ & $t_{21}$ & $\mathrm{t}_{12}$ & $\mathrm{t}_{\mathrm{mn}}$ \\
\hline$t_{30}$ & $t_{31}$ & $t_{22}$ & $\mathrm{t}_{1 \mathrm{n}}$ \\
\hline $\mathrm{t}_{40}$ & $\mathrm{t}_{41}$ & $t_{32}$ & $t_{2 n}$ \\
\hline$t_{50}$ & $t_{51}$ & $\mathrm{t}_{42}$ & $t_{3 n}$ \\
\hline $\mathrm{t}_{60}$ & $\mathrm{t}_{61}$ & $\mathrm{t}_{52}$ & $\mathrm{t}_{4 \mathrm{n}}$ \\
\hline $\mathrm{t}_{70}$ & $t_{71}$ & $\mathrm{t}_{62}$ & $t_{5 n}$ \\
\hline $\mathrm{t}_{80}$ & $\mathrm{t}_{81}$ & $\mathrm{t}_{72}$ & $\mathrm{t}_{6 \mathrm{n}}$ \\
\hline$t_{90}$ & $t_{91}$ & $\mathrm{t}_{82}$ & $\mathrm{t}_{7 \mathrm{n}}$ \\
\hline
\end{tabular}

\begin{tabular}{|l|l|l|l|}
\hline blade\# & $\begin{array}{l}\text { sensor } \\
1\end{array}$ & $\begin{array}{l}\text { sensor } \\
2\end{array}$ & $\begin{array}{l}\text { sensor } \\
\mathrm{n}\end{array}$ \\
\hline 1 & $\delta_{11}$ & $\delta_{12}$ & $\delta_{13}$ \\
\hline 2 & $\delta_{21}$ & $\delta_{22}$ & $\delta_{23}$ \\
\hline 3 & $\delta_{31}$ & $\delta_{32}$ & $\delta_{33}$ \\
\hline $\mathrm{m}-1$ & $\delta_{\mathrm{m}-1,1}$ & $\delta_{\mathrm{m}-1,2}$ & $\delta_{\mathrm{m}-1,3}$ \\
\hline $\mathrm{m}$ & $\delta_{\mathrm{m} 1}$ & $\delta_{\mathrm{m} 2}$ & $\delta_{\mathrm{m} 3}$ \\
\hline
\end{tabular}

\section{Common visualisation methods}

\section{Stack Pattern}

Static positions of blades on the circumference and their inter-blade-spacing are used to identify them, verify provided probe positions and properly align TOA sequences coming from different sensors. Stack pattern (Fig. 3) is a footprint of the blade row and can be also utilised as a reference of the rotating system and also in blade health monitoring to detect a crack or a foreign object damage (FOD).

\section{Blade Waterfall}

The basic way of presenting input data for a selected sensor is to plot waveforms of dynamic component of scaled TOA data (Fig. 4). The chart shows aliased tip deflection signals for successive blades, with the first blade at the bottom. 
You can plot the deflection in function of revolution number or time or rotational speed to do quality check of sensors and look for blades with different characteristics of low-order vibration (high responding blades). When speed is altered it is possible to roughly determine the resonance frequencies.

After zeroing the data [10] and fitting sensor indications to the oscillator model (SDOF) with help of the Least Squares method [2] it is possible to plot the waveform of estimated amplitude i.e. non-aliased deflection signal, and even visualise phase using colours [6].

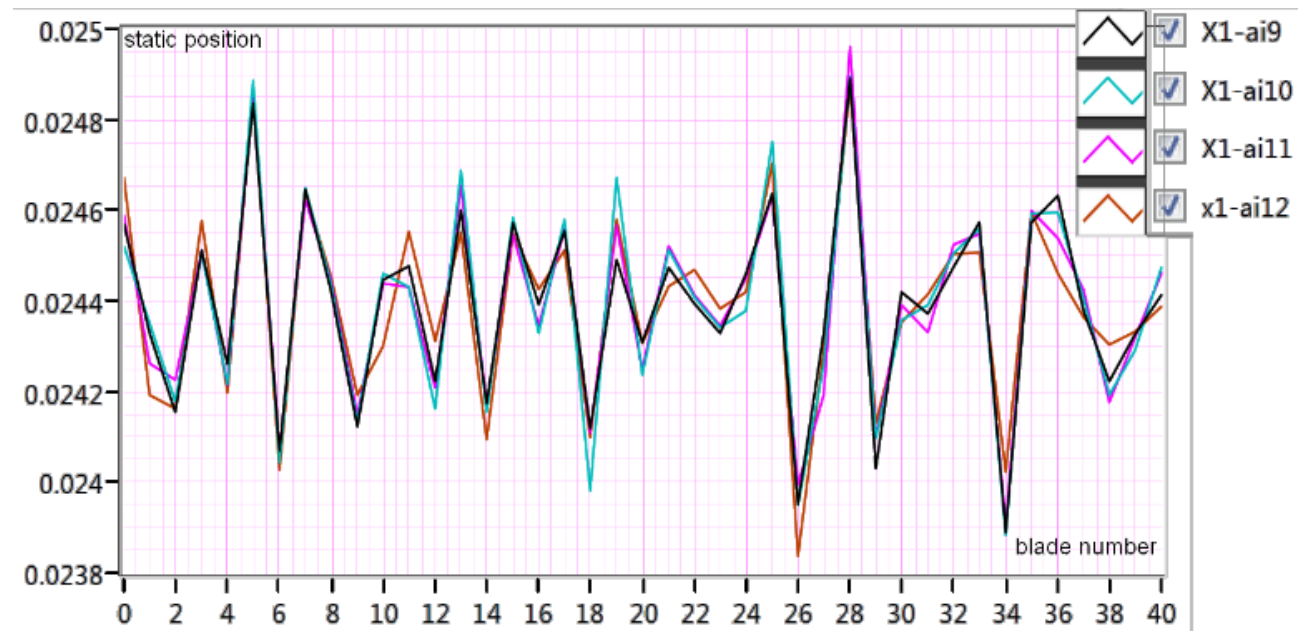

Fig. 3. Example of stack plot (4 sensors)

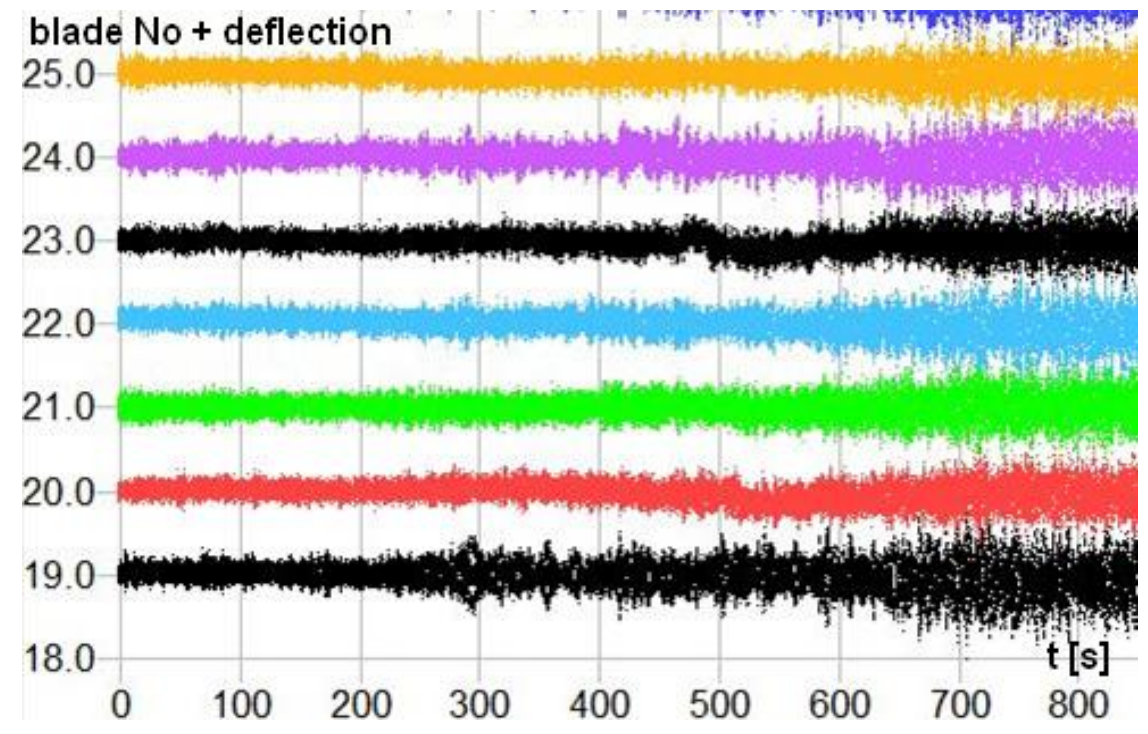

Fig. 4. Example of blade waterfall 
Data management techniques for blade vibration analysis Techniki zarzadzania danymi w analizie drgań topatek

Single blade spectrum

Individual blade vibration in successive rotations can be analysed in frequency domain with Fast Fourier Transform. The graph shows the logarithmic power spectral density change during the deceleration of the selected blade in the bandwidth from 0 to a half of the rotational speed ( $1 / 2$ EO) (Fig. 5). You can measure the fractional frequency and the amplitude of asynchronous vibration. The spectrogram can be generated even on-line by taking successively tip deflection data from a few rotations to the FFT window.

With one sensor the bandwidth is limited by half of the rotational frequency $(1 / 2$ EO). Any components with higher frequencies are presented as aliases, so the spectrum requires reconstruction to measure the real frequency of blade vibration. It is more convenient to plot the rotation number instead of time on $\mathrm{x}$ axis and engine order instead of frequency on y axis to maintain constant resolution.

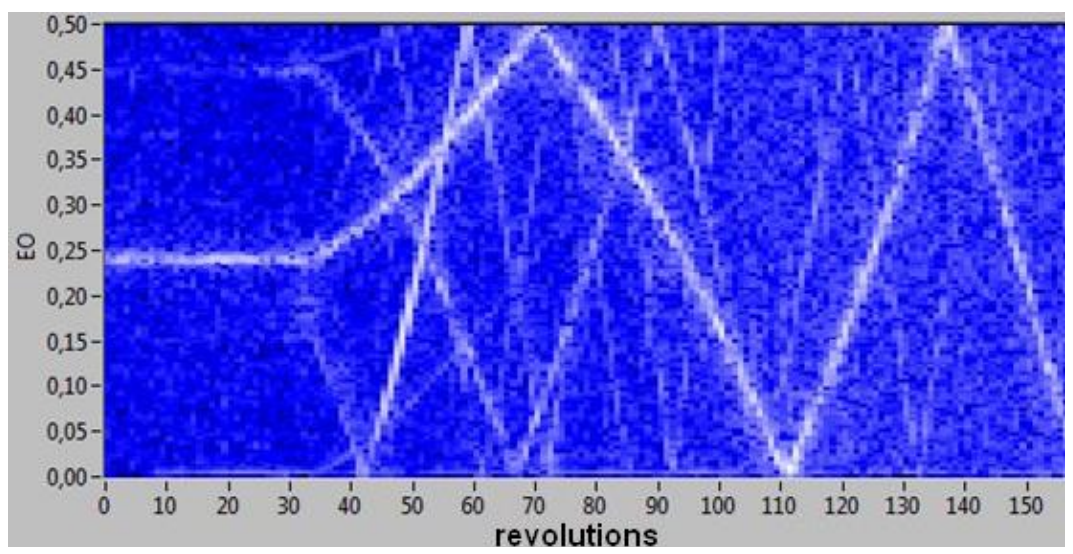

Fig. 5. Example of a single-blade spectrum

Travelling Wave Plot (All-blade Spectrum)

Asynchronous vibration such as flutter, rotating stall or surge engage the whole bladed disk rather than individual blades and therefore all-blade spectrum is a preferred method to observe them (Fig. 6 ). When deflections of all blades are transformed together, the sampling rate is increased by the number of blades $b$ and the bandwidth is equal $1 / 2 \mathrm{EO} b$.

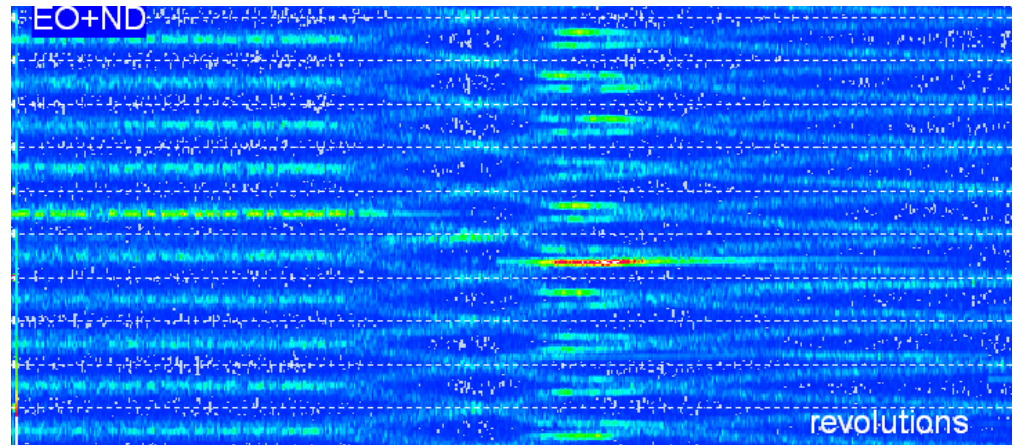

Fig. 6. Example of Travelling Wave Plot 
Campbell Diagram

Campbell diagram is the final form of presentation of forced vibration's parameters, presenting responses of blade or system modes excited by: 1) engine orders (integral or synchronous vibration) or 2) flow-related forces (non-integral vibration).

Amplitude and frequency of vibration is presented in the function of rotational speed in reference to orders of excitation forces.

\section{Generic analysis tools}

Due to the responsibility connected with testing of aviation product and legal requirements the analyses are required to be composed of documented operations. It is important that not only report's modifications, but also source code revisions and used data are tracked and archived. Moreover, it is worth eliminating manual operations and replacing them by software programmes in order to decrease the influence of the human factor on results. It is very rare that an action is done only once, thus it is almost always worthwhile to write a programme or a script.

We try to avoid proprietary data formats as human readable or open data formats can be easily accessed and managed without custom software. Therefore data files and source code in text format are preferred. If binary files are required to save disk space, we use open formats or raw files with a text header in a separate file.

In order for an analysis be repeatable, in both its final and earlier versions, we track changes of measurement configuration, revisions of source code and store archive data and libraries that are necessary to launch a code.

For the purpose of processing measurement signals we use high level programming languages, such as LabView and Matlab, which have been equipped with tools for operations on sampled signals and creating of charts. LabView (just like Matlab) has a rich library of numerical procedures and skilfully processes big matrices and additionally it effectively handles various measurement systems. However, a graphical source code and the binary vi format of files make the code version tracking and batch processing rather difficult. Moreover, interactive work in the way similar to Matlab and other interpreted languages is impossible. Despite all of this, fast prototyping of algorithms is possible in LabView, since it is not difficult to create a programme with a standard graphical interface according to the simplest Immediate SubVi pattern.

Writing of a bigger programme in LabView is similar in its complexity to other tools and requires using of advanced technologies and design patterns, such as state machines, queues and event loops [15]. For the purpose of integrating prototype subprogrammes into a bigger programme, thorough knowledge of the software suite is necessary. Nevertheless, LabVIEW and PXI hardware create a set of wellsuited tools to build scalable and flexible data acquisition solutions and implement Real Time Analysis functionality [4]. 
Data management techniques for blade vibration analysis

Techniki zarzadzania danymi w analizie drgań topatek

On the other hand, Matlab should be regarded as the reference environment for analytical researches due to the following:

- Capability of reading data in various formats,

- Operating on whole channels and matrices (in contrast to Excel),

- Interactive work and subsequent building of scripts on the basis of the orders' history and fast passing to batch processing,

- Convenient access to indirect results in workspace in tables and charts,

- Many tools for data visualisation.

These features are also available in NI Diadem, promoted as a report generation tool. It provides access to many data sources, convenient GUI and templates for charts .tdv and reports .tdr, which can be repeatedly used for successive datasets. However, the script language of Matlab is a standard in scientific calculations, has rich libraries, many solutions with open code and many users in contrast to the unhandy VBA language implemented in Diadem.

Comprehensive toolsets for creating reports in the html, pdf, doc formats are available in Matlab and LabView. In practice, reports generated in these formats have not met our expectations: html pages are not suitable for publication, it is hard to introduce changes to pdf files, and doc documents require too much manual editing.

MATLAB offers at least two methods to generate reports: powerful Report Generator Toolbox and easier to use built-in publish function. Both mechanisms enable to customize the style of the report using style sheets (templates). Publish function activates an automatic report generator, which creates a document in the desired format (html, xml, latex, doc, ppt, pdf) based on code, results of the script, markup commands and comments in the code.

Using MS Office file formats and tools in the process of research data analysis is not the best idea, since the Microsoft technologies, such as ActiveX and VBA are ageing and their operation can change in subsequent versions of the suite in an unexpected way. VBA scripts often have to be launched through trial and error and causes of problems cannot be determined.

If we care about traceability, it is better to avoid using proprietary software and libraries whose implementation is not disclosed. Open source software is better suited to the scientific and research use. It is hard to use the rich capabilities of commercial software suites if we do not control operations conducted by them. Learning advanced capabilities of proprietary programmes requires time and effort and it is better to dedicate them to open source projects, in which we can adjust libraries to our needs or influence their development.

One of the best Matlab alternatives is Python, a modern, general-purpose, objectoriented, high-level programming language with open and powerful scientific libraries (numPy, sciPy, mathplotlib, pandas), large community of users, freely available documentation, tutorials and code examples [16], [17]. It can be installed on most operating systems, preferably in form of a scientific distribution and with some supporting tools such as revision control software. 
Python's syntax differs from Matlab, because it has been designed for maximum readability and flexibility. The ecosystem built around the Python can replace Matlab in most applications, while offering many opportunities unavailable in it. The mentioned scientific libraries and Spyder (Integrated Development Environment) resemble Matlab, so you can start working in a short time if you have the basics of programming in Python.

\section{Report Generation Framework}

Reports prepared at ITWL may have different forms depending on the described problem, receiver and used tools. However, the main part usually contains the most important facts and summary, and detailed results are presented in appendices. We were looking for a tool that would support the preparation of appendices, which usually consist of introduction and a sequence of numbered and signed charts.

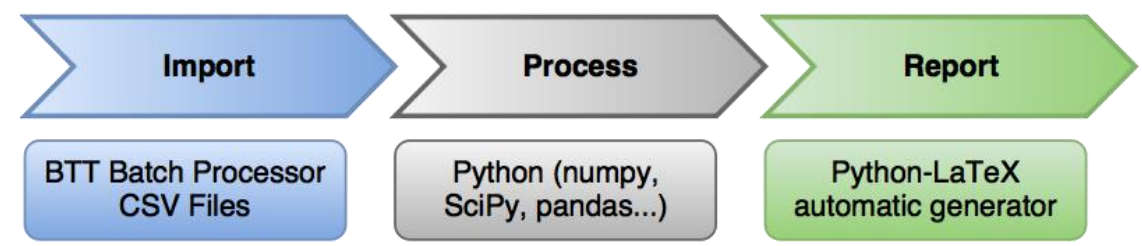

Fig. 7. Simplified workflow of BTT data analysis and report generation with the use of Python, RGF \& Batch Processor

We decided to combine readily available tools to support processing and publishing blade vibration results (Fig. 7). LaTeX is a mature and sophisticated environment for desktop publishing, convenient for automated file generation and manipulation thanks to its source markup language. Python programming language with its ecosystem is capable of solving both automation and data analysis tasks. These two can be combined together and with revision control software (git/gitlab), python virtual environments and IPython Notebooks to facilitate traceability and reproducibility.

\section{Project idea and structure}

The RGF, although named a "framework" at the beginning of a project, is more a set of tools and libraries (Fig. 8). The most important contribution created at ITWL is RGF Render python module responsible for automated plots, tables and tex source creation. Its main design characteristics are:

- Loose coupling with rest of the RGF python environment. Rendering is independent from data sources or calculations and relies on conventions in structure and behaviour of data container(s) and plot definitions passed to automated rendering engine. These conventions are kept as minimal as possible and make use of duck typing.

- Acts (in specific places) as a thin wrapper around existing libraries to provide most of the underlying capabilities and avoid reinventing the wheel. For example all avablive matplotlib plot arguments can be (optionally) specified in plot definition, or arbitral parameters can be passed to jinja2.Template.Render() call. 
Data management techniques for blade vibration analysis

Techniki zarzadzania danymi w analizie drgań topatek

- Additional plot formatting and captioning actions can be implemented in custom objects (functions, methods, classes) passed to the automated rendering engine at runtime, fulfilling Inversion of Control principle.

The Render module has high cohesion and its contents are open to extension by object substitution or inheritance/decoration, promoting code reuse. The RGF Render code itself also reuses existing resources.

Matplotlib is de-facto a standard python plotting library producing publicationquality plots. Although feature-rich and object oriented, it aims to make easy things easy and hard things possible and provides procedural Matlab-like API.

Jinja2 is a templating engine for Python (based on the Django web framework) that has configurable syntax and is easy to debug. The basic template rendering example fits in about 20 lines of python code, most of them being LaTeX-friendly syntax definition. Filling the template with charts can be as simple as a single forloop over plots list.

Templates for common report and presentation types used at ITWL have been developed in form of *.tex files. LaTex provides high quality publication tools and handles tables, plots, automatic lists and indexes, page numbering, caption numbering, references etc., while maintaining editable text file format after rendering and simple template structure.

The rendered *.tex source can be modified in TeXstudio or other editor to add paragraphs, one-off diagrams or edit captions. Tex files can be easily tracked under version control and git can be also used for merging different versions made by different users.

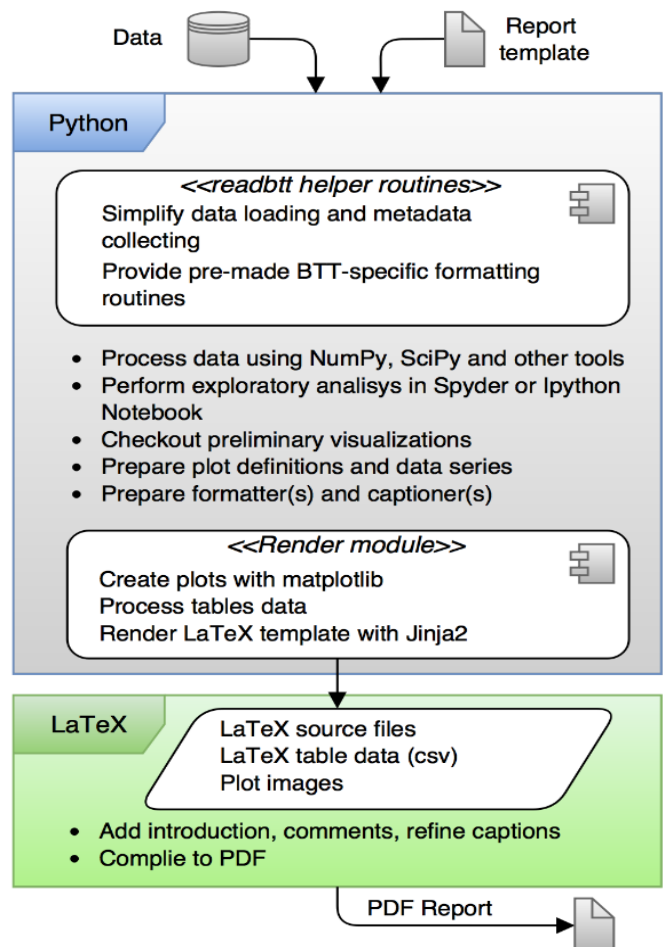

Fig. 8. Flow chart of a Python script generating a report in tex and pdfformat 
Automated rendering engine can be accompanied by custom modules providing previous steps. For example, the 'readbtt' module has been created to support seamless loading of Rolls Royce BTT Batch Processor [9] files together with metadata collecting and to provide BTT-specific plot formatting and captioning. However, its metadata features are virtually independent from rendering and are also used separately.

\section{Batch processing}

Python and RGF features, such as string processing, regular expressions and lists enable to batch process the whole directory tree in a single script in a few lines. RGF enables to select data from several files and generate review charts. In a typical scenario successive LFC cycles are stored in separate datasets (Fig. 9) and evolution of blade response is to be shown.

Alternatively you can define jobs for batch processing without modifying the reference script. A list of input files, data series and plot definitions can be provided as a YAML file in a human readable-format (table 3). It doesn't matter for the RGF Renderer whether the required structures have been statically defined or constructed on the fly.

External tools (from Unix ecosystem or Windows) including proprietary software can be called from Python using command line parameters or ActiveX. Alternatively the Unix make command can be used to build complex analyses combining codes in compiled languages (C++, Fortran) with Python and Latex.

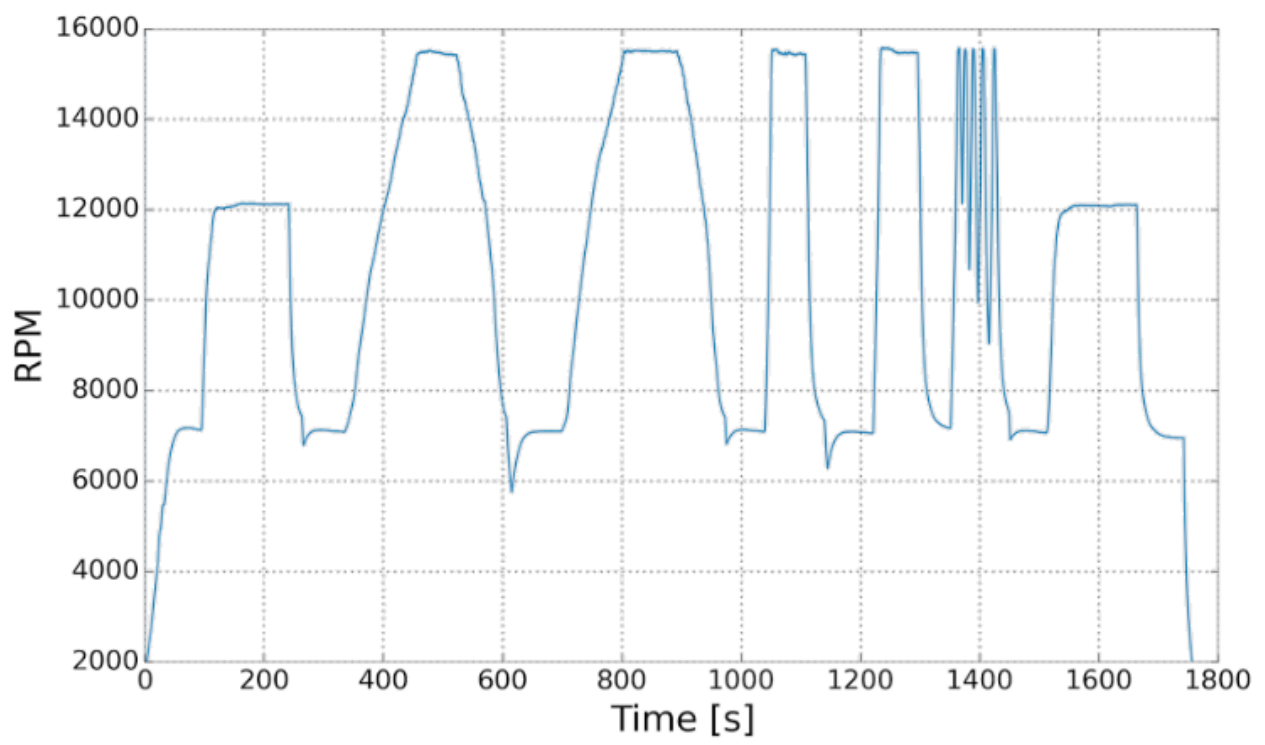

Fig. 9. Example of a test-run 
Data management techniques for blade vibration analysis

Techniki zarzadzania danymi w analizie drgań topatek

Table 3. Example of a batch file in the YAML format

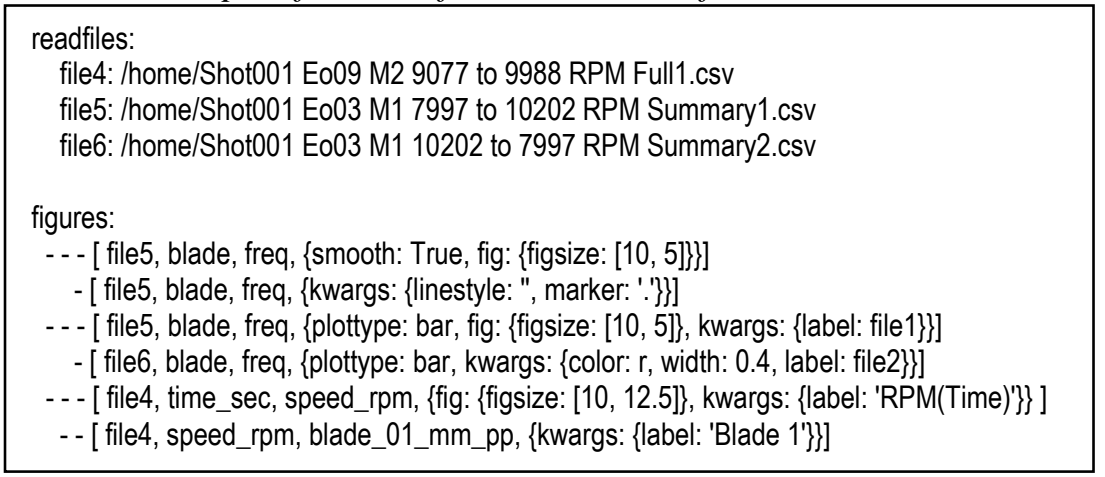

The presented approach, based on files in the text format with revisions controlled by git, provides traceable, reproducible analysis results in form of publication quality documents.

\section{Interactive data analysis}

Real interaction with data is possible only with the use of an interpreted language, providing access to intermediate results in the workspace. When operations performed during processing of vibration data are tracked, you are able to reproduce the analysis procedure and document its implementation. IPython is a Python shell designed for interactive computing, in which sessions' history is kept forever and can be exported to scripts. IPython is built in the main window Spyder IDE, so you can use them in bottom-up programming, expanding a collection of shell commands to sophisticated functions and modules, being able to debug the code and observe intermediate results. Consequently, you can perform exploratory data analysis and devise new models and analysis methods bit by bit. There are plenty of handy modules in Python which enable i.a.:

- Accessing other data formats, databases and network communication,

- Numerical calculation and statistical operations on whole channels (array operation) with the use of numPy, sciPy and pandas,

- Interfacing the operating system and input/output hardware.

Another powerful environment for interactive scientific calculations and data analysis is provided by Ipython notebooks, which combine results of Python instructions with instant generation of publication-ready documents [16], [18]. The data processing and chart generation functionality implemented in the RGF or other Python code may be called from cells of IPython Notebooks (Fig. 10). Instructions in their cells are executed on demand and new results appear in the web browser immediately, so analyses can be performed and documented step by step. Similar report generation tools available in Matlab either generate static documents (publish) or depend on Microsoft technologies (Matlab Notebook in MS Word). 
However, RGF introduces yet another set of tools to the organization's internal toolbox. This may be undesirable, especially when there is strong reliance on already present solutions and neither Python, nor Latex is being used. Even with Python, in some basic cases generating charts directly may be preferable. Moreover, users have to be familiar with Python programming and Unix tools to be able to use it effectively. Last, but not least, Python/LaTeX ecosystem may lack unique or specific features provided by the proprietary software.

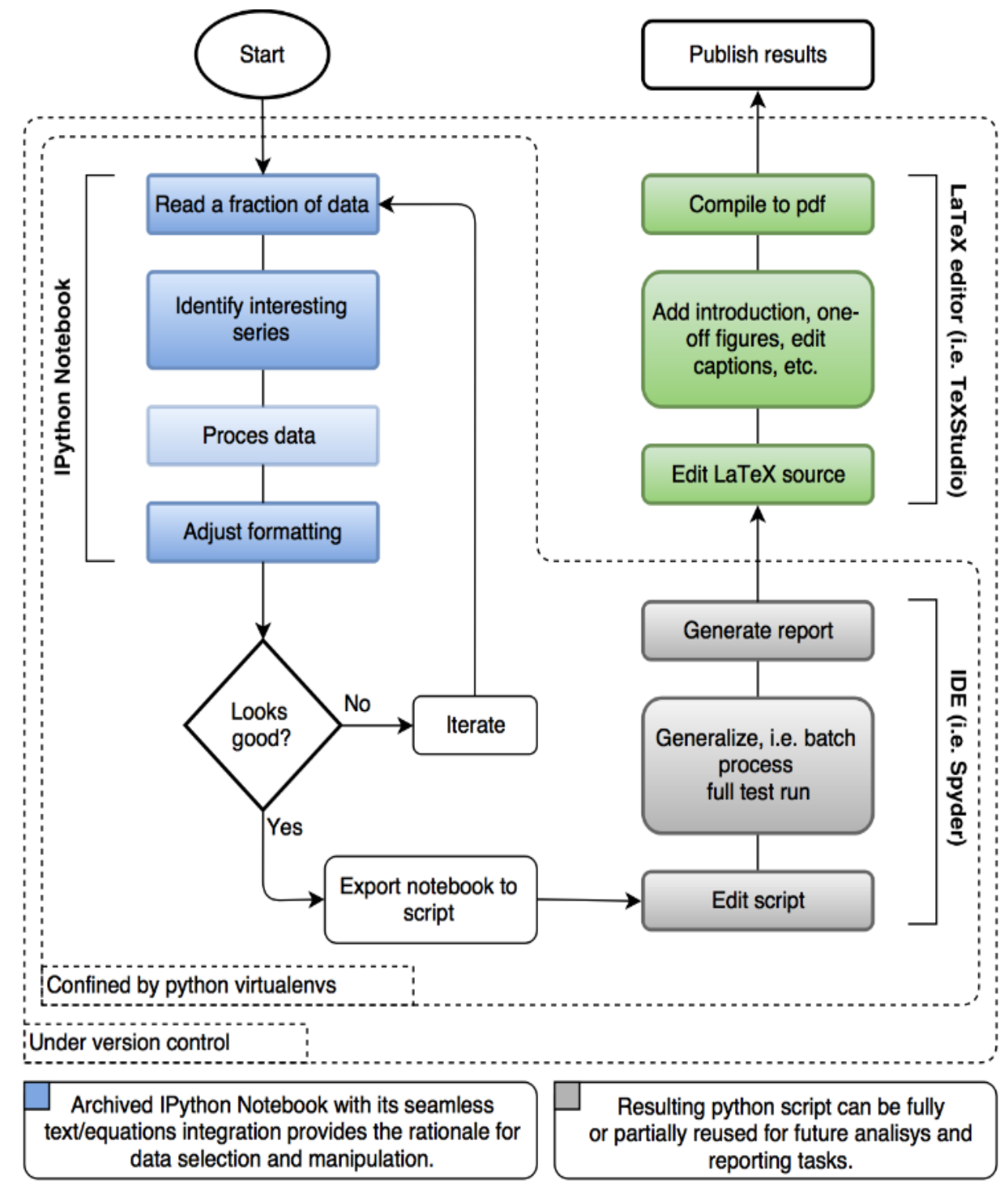

Fig. 10. Interactive data analysis in the Python/RGF ecosystem 
Data management techniques for blade vibration analysis Techniki zarzadzania danymi w analizie drgań topatek

\section{Example results}

We applied the RGF and IPython Notebooks to present selected results of vibration estimation from the BTT Batch Processor for the resonance M2 EO7. Full (Fig. 11) and Summary (Fig. 12) CSV files have been imported [9]. You can verify whether Batch Processor correctly identified the resonance by checking the phase plot (Fig. 11c).
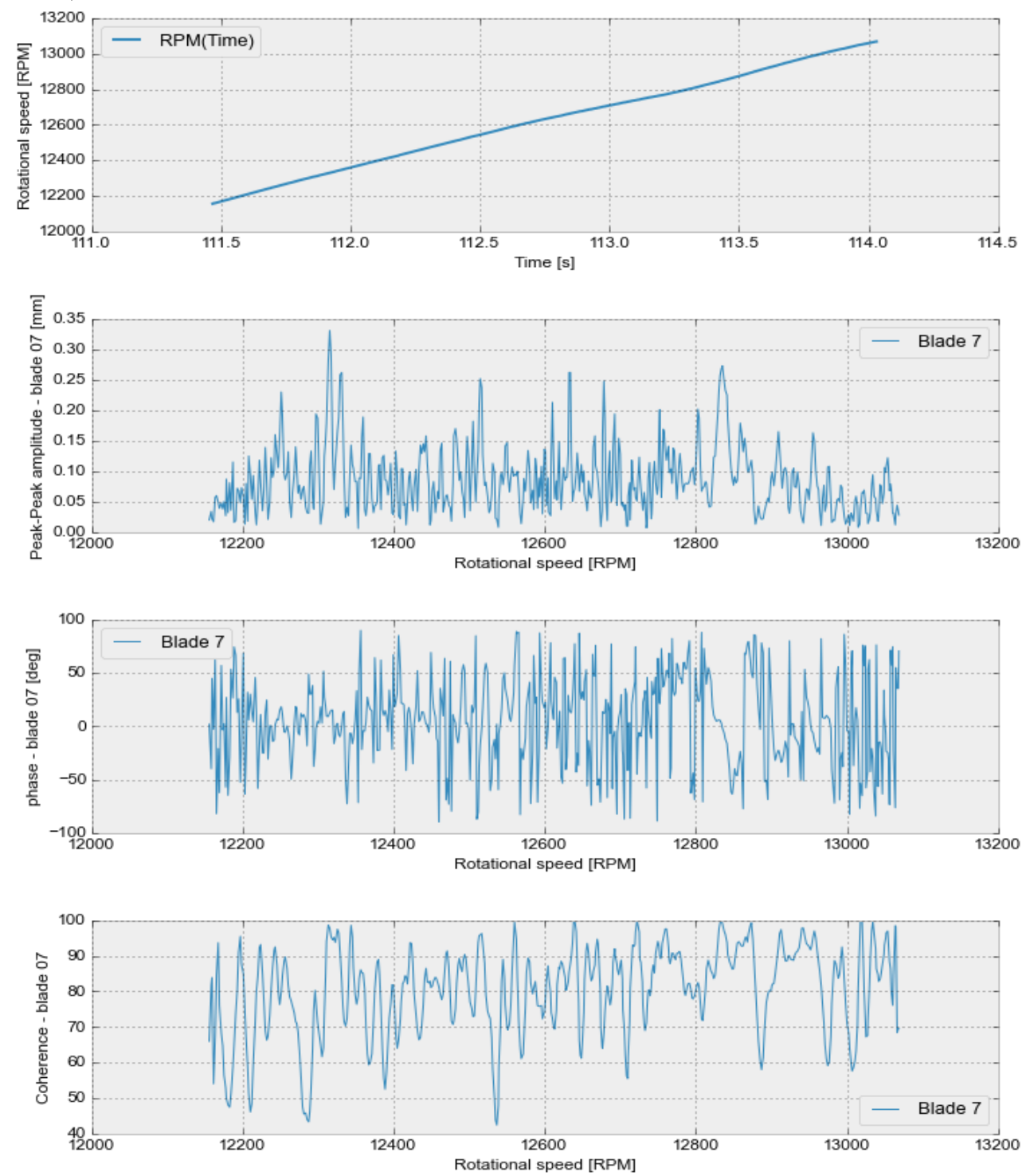

Fig. 11. Crossing of M2 EO7 resonance:

a) rotational speed, b) amplitude, c) phase and d) coherence 

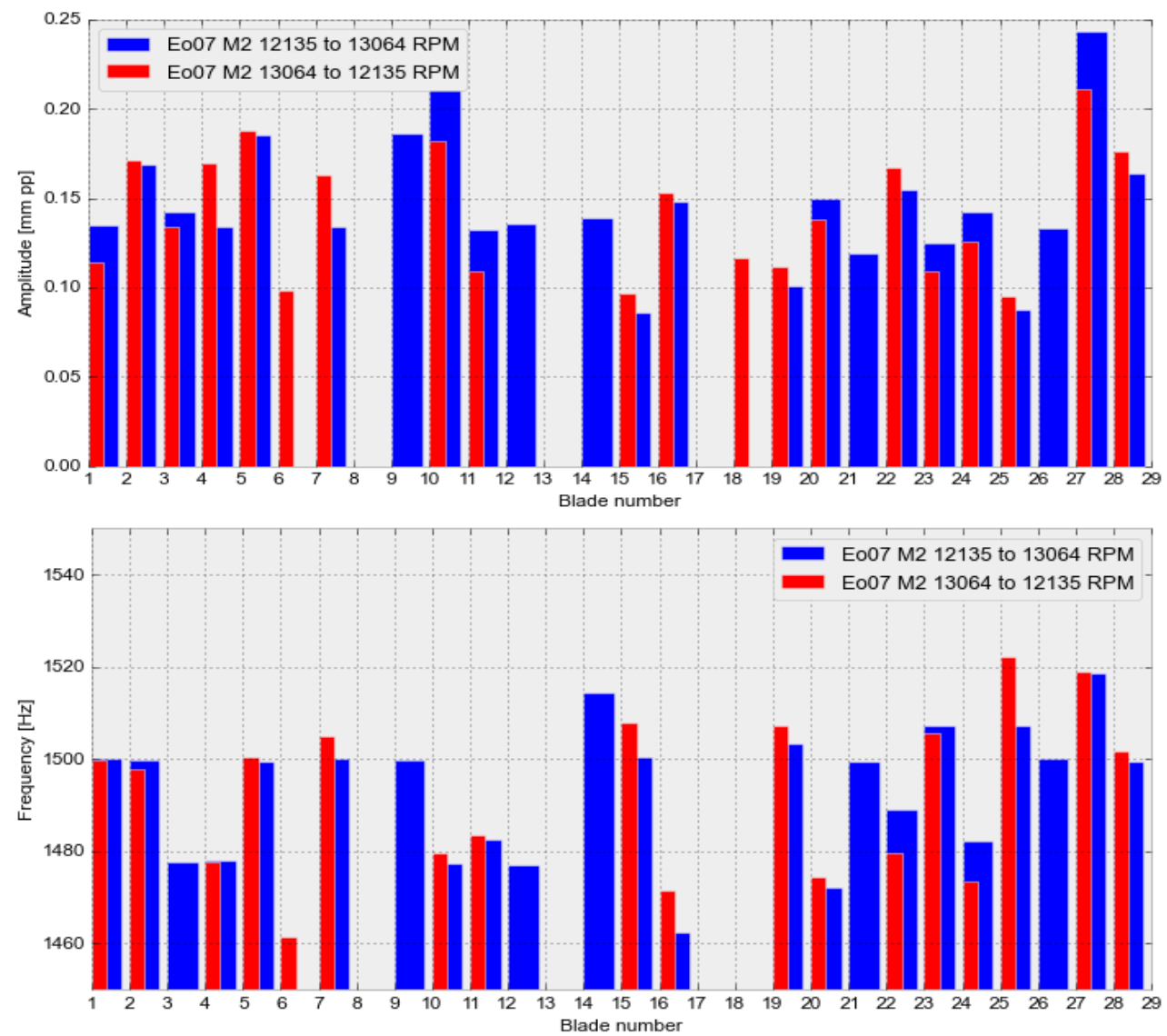

Fig. 12. Amplitude and frequency of M2 EO7 resonance

\section{Acknowledgements}

The project has been supported by the Polish Government in 2012-2014; agreement No PBS1/B4/5/2012.

\section{References}

[1] B. Hayes (chair) "ANSI/ISA-107.1-2013 Industry Standard File Format for Revolution-Based, Tip Timing Data", www.isa.org

[2] R. Przysowa Analysis of synchronous blade vibration with the use of linear sine fitting, Journal of KONBiN, 2(30), pp. 5-20, De Gruyter Open (2014).

[3] R. Przysowa "Inductive Sensors for Blade Tip-Timing in Gas Turbines", Test Cell and Controls Instrumentation and EHM Technologies for Military Air, Land and Sea Turbine Engines, MP-AVT-229-10, Rzeszów (2015)

[4] R. Przysowa, P. Gazda "Direct sampling and phase detection of inductive sensor signal”, NIDays, Warszawa (2015) 
Data management techniques for blade vibration analysis

Techniki zarzadzania danymi w analizie drgań topatek

[5] N. Herbring at al. "Chapter 8 - Data Capture, Management and Analysis" in: "Gas Turbine Engine Test Cell Instrumentation", Final Report of Task Group RTG-057, TR-AVT-180, www.cso.nato.int (2014)

[6] "Agilis AATAS Software - A complete suite of software for a high cycle fatigue testing of rotating turbo machinery from conception to data reduction" www.agilismeasurementsystems.com (2012)

[7] "Overview of Blade Vibration Monitoring Capabilities", Hood Technology Corporation www.hoodtech.com (2011)

[8] M. Zielinski, G. Ziller "Noncontact Blade Vibration Measurement System for Aero Engine Application". 17th International Symposium on Airbreathing Engines, Paper No. ISABE-2005-1220 Munich (2005)

[9] O. Jousselin "Blade Tip Timing Batch Processor User Guide" DNS147027, Rolls-Royce plc (2011)

[10] "BT Blade Timing Non-Contact Testing System" APEX Turbine Testing Tech-no-lo-gies, apexturbine.com (2014)

[11] "Capacitive Blade Tip Clearance \& Tip Timing measurement system" Fogale nanotech, www.fogale.fr (2012)

[12] "Blade Tip Timing System" Rotadata brochure, Derby (2014).

[13] P. Russhard "BTT MultiTool software" http://emtd-measurement.com/ (2015)

[14] P. Russhard "BTT Data Zeroing Techniques", MFPT and ISA's 59th International Instrumentation Symposium (2013).

[15] P. A. Blume "The LabVIEW style book". Pearson Education (2007).

[16] R. Johansson "Introduction to Scientific Computing in Python", github.com/jrjohansson/scientific-python-lectures (2014)

[17] W. McKinney "Python for data analysis: Data wrangling with Pandas, NumPy, and IPython", O'Reilly Media, Inc.. (2012).

[18] H. Shen "Interactive notebooks: Sharing the code" Nature, 515(7525), 151152 (2014).

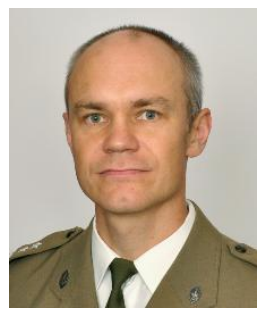

Radostaw Przysowa PhD Eng. works as a tip-timing specialist in Aero- Engine Department of ITWL. He has remarkable programming skills, including object oriented programming, digital signal processing and data mining. He is also involved in research management and commercialization. Alumnus of Top 500 Innovators Programme. (Share: 50\%).

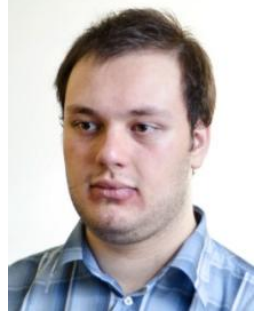

Aleksander Tuzik is a student of Mechatronics at Wroctaw University of Technology, an advanced Python coder and an active member of the research team "Space Is More". (Share: 50\%). 


\section{TECHNIKI ZARZĄDZANIA DANYMI W ANALIZIE DRGAŃ LOPATEK}

\section{Wprowadzenie}

Zazwyczaj szczegółowo planuje się badania eksperymentalne silników i definiuje się zestaw obserwowanych parametrów, ale często zbyt mało uwagi poświęca się przygotowaniu zbierania i przetwarzania danych pomiarowych. Najlepiej, gdy narzędzia do wyznaczenia potrzebnych parametrów są gotowe przed testami i mogą działać online. Zazwyczaj analiza danych off-line zajmuje później więcej czasu niż się zakłada, ponieważ z dostępem do danych związany jest określony nakład pracy. Często potrzebne informacje nie są gromadzone w jednym miejscu, mają niewystarczające metadane, mają różne formaty lub zapisane są $\mathrm{w}$ innej funkcji czasu. Inżynierowie toną w danych i na ogół są w stanie analizować tylko kilka procent zapisów.

Bezdotykowy pomiar drgań łopatek wykonywany jest w trakcie rozwoju silnika w celu sprawdzenia jakości projektu stopnia wirnikowego oraz jego integralności strukturalnej i jest podstawowym narzędziem do ograniczania ryzyka zmęczenia wysokocyklowego.

Współczesne programy rozwoju silników obejmują tysiące godzin testów, w tym badań podstawowych modułów silnika oraz silnika w całości. Przygotowanie aparatury to bardzo pracochłonny i kosztowny proces obejmujący rozmieszczenie czujników, okablowanie, znakowanie i zarządzania informacją o lokalizacji czujnika.

Sposób zbierania, dokumentowania, przetwarzania i archiwizacji danych pomiarowych należy projektować równolegle $\mathrm{z}$ instalacją pomiarową. W przypadku metody tip-timing, mamy do czynienia $\mathrm{z}$ dużą wrażliwością uzyskiwanych wyników analizy od liczby i rozmieszczenia czujników i dlatego informacje o zmianach konfiguracji muszą być śledzone i dostępne przy przeglądaniu danych.

Pomiar i analiza drgań łopatek powinna zapewnić:

- parametry drgań poszczególnych łopatek, takie jak częstotliwość, amplituda i fazę w funkcji prędkości obrotowej (diagram Campbella);

- charakterystyka drgań ułopatkowanej tarczy- średnica węzłowa, częstotliwość, amplituda i faza;

- identyfikacja rezonansów - postać drgań, prędkość obrotowa i rzędowość wymuszenia (EO);

- wskazanie łopatek, które różnią się od innych tzw. łopatek mocno odpowiadających 
Data management techniques for blade vibration analysis

Techniki zarzadzania danymi w analizie drgań topatek

Podobnie jak w innych systemach pomiarowych na hamowni, poziom i trend drgań łopatek muszą być na bieżąco monitorowane podczas eksperymentów stoiskowych (funkcja Czerwonej lampki).

W przypadku ryzyka uszkodzenia uruchamia się alarm, a nawet wyłączany jest silnik. Mimo wszystko nadal jest potrzebny inżynier, który obserwuje odpowiedzi łopatek w trakcie prób silników, których celem jest rozwój produktu, certyfikacja lub badania przyczyn awarii.

\section{Zarządzanie danymi}

Testowanie silnika wymaga zaawansowanych metod przetwarzania dużych zbiorów danych i zarządzania konfiguracją pomiarową. W tej części dokonano przeglądu najlepszych praktyk w zakresie zarządzania pomiarami drgań łopatek, obejmujących akwizycję, dokumentowanie i porządkowanie danych pomiarowych, a także wizualizację wyników i raportowanie.

\section{System bezdotykowego pomiaru drgań topatek}

System pomiaru drgań łopatek jest zwykle częścią dużej instalacji pomiarowej działającej na hamowni [5]. Jego struktura jest podobna do systemów pomiaru sygnału dynamicznego (DSA), które często są stosowane równocześnie do analiz sygnałów tensometrów, szybkozmiennego ciśnienia lub drgań korpusu. System pomiarowy ma zazwyczaj postać komputera przemysłowego o strukturze modułowej podłączonego do sieci Gigabit Ethernet, opartego o Windows lub Linux i montowanego w szafie wraz z interfejsami czujników (modułami akwizycji danych i kondycjonowania sygnałów). Zwykle używana jest synchronizacja czasu $\mathrm{z}$ dokładnością do mikrosekund (IRIG B, Inter-Range Instrumentation Group), aby móc porównać wyniki metody bezdotykowej $\mathrm{z}$ systemami pomiaru sygnałów dynamicznych.

Do przechowywania danych używane są serwery plików, takie jak lokalna macierz RAID lub dysk sieciowy Network Attached Storage (NAS). Wyniki pomiarów mogą być udostępniane za pośrednictwem sieci lokalnej lub nawet w firmowym intranecie. Ich kopie są często wysyłane kurierem do innych lokalizacji na dyskach twardych i lub pamięci flash. Zapasowe kopie danych są przechowywane na zewnętrznych dyskach twardych lub taśmach magnetycznych.

Na rynku dostępne jest kilka gotowych systemów pomiaru drgan łopatek, których konfiguracja jest zazwyczaj dostosowywana do potrzeb klienta [6] - [13]. Alternatywnie, system pomiarowy może być zbudowany samodzielnie z wykorzystaniem komercyjnie dostępnych składników (Rys.1) [4].

Pakiet oprogramowania BTT zazwyczaj składa się z dwóch głównych programów:

- część online, obejmująca pomiar, odtwarzanie i uproszczone analizy realizowane w trybie czasu rzeczywistego, 
- część do analizy offline.

Dostępne są również dodatkowe narzędzia np. do projektowania rozłożenia czujników, symulacji drgań synchronicznych.

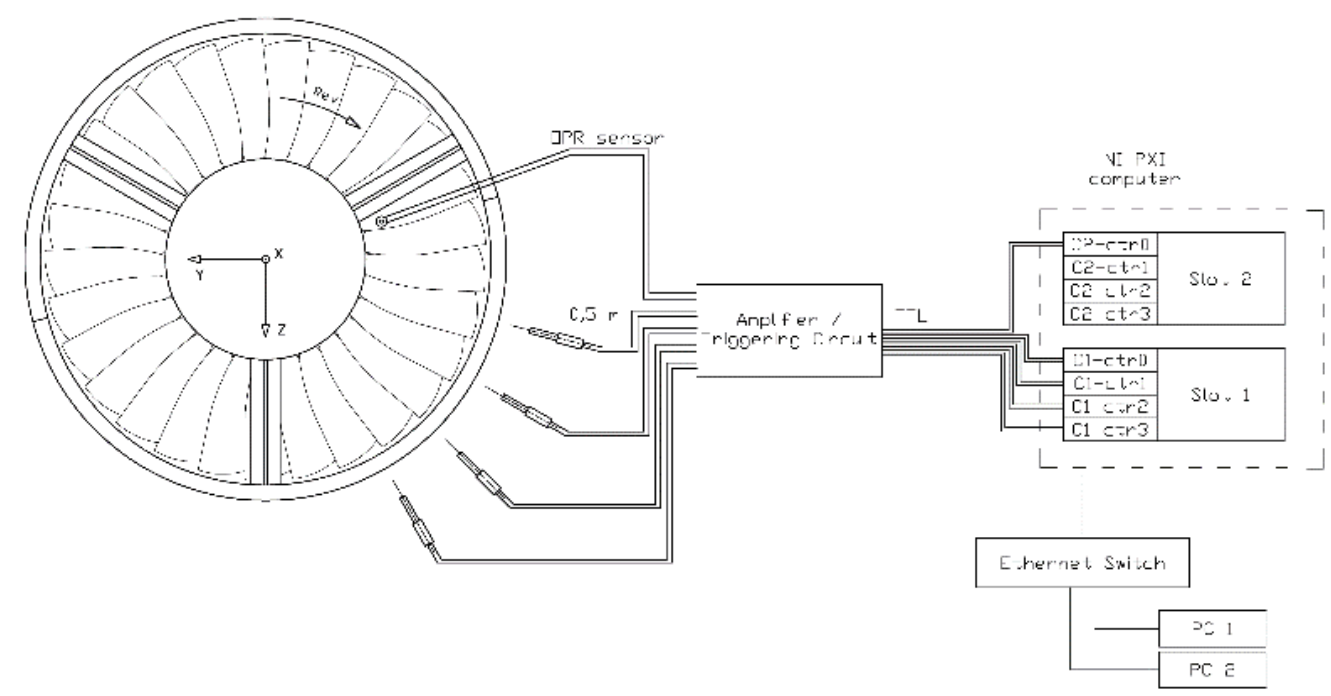

Rys. 1. System pomiaru drgań topatek opracowany $w$ ITWL, oparty na komputerze PXI

Pierwszy pakiet może zwykle pracować zarówno w czasie rzeczywistym oraz w trybie odtwarzania zapisu (Replay). W obu trybach oferowana jest podobna funkcjonalność, obejmująca statystyczną redukcję danych, transformaty widmowe oraz wyznaczenie parametrów drgań poprzez dopasowanie metodą najmniejszych kwadratów. Wyniki obliczeń przedstawione są jako wykresy (przebieg drgań, widmo pojedynczych łopatek i wszystkich łopatek) lub tabele, a także mogą być eksportowane $\mathrm{w}$ popularnych formatach. Można również zdefiniować w jaki sposób dane są zapisywane i wybrać fragmenty do dalszej analizy w pakiecie off-line. Każdy stopień wirnika jest zwykle monitorowany przez oddzielny podsystem i innego operatora.

Pakiet do analizy off-line ma dostarczyć ilościowych parametrów drgań w postaci tabel w wyniku transformacji widmowych i dopasowania danych TOA do modelu oscylatora. Mimo wszystko konieczna jest wizualizacja wyników analizy, aby inżynierowie mogli przejrzeć wyniki i wyciągnąć wnioski. Aby rozpocząć automatyczną ocenę drgań, operator systemu musi określić parametry takie jak zakresy prędkości rezonansowych, rzędowość wymuszenia, rodzaj analizy. 
Data management techniques for blade vibration analysis

Techniki zarzadzania danymi w analizie drgań topatek

\section{Format danych pomiarowych}

W standardowej metodzie bezdotykowej tylko jedna wartość (określana jako czas przyjścia - TOA) jest mierzona przez każdy czujnik w trakcie pojedynczego obrotu. Dane TOA są przechowywane w postaci zapisów czasu licznika cyfrowego (najczęściej 32-bitowa liczba całkowita bez znaku) lub alternatywnie jako czas w sekundach - liczba zmiennoprzecinkowa podwójnej precyzji (64 bity). Chociaż drgania łopatek są zbyt rzadko próbkowane w metodzie bezdotykowej, znaczny strumień danych (ok. 100-200 kbajtów/s na kanał) musi być obsłużony przez system akwizycji danych. Dane z czujników mogą być w pewnych warunkach przychodzić w różnym tempie, dlatego też są zwykle zapisywane w oddzielnych plikach. Czujnik odniesienia (raz-na-obrót) znajduje się w ostatnim lub pierwszym kanale.

Wartości TOA z każdego czujnika są zapisywane w osobnym pliku binarnym, który zawiera sekwencję czasów przyjścia w formacie zmiennoprzecinkowym lub odczytów liczników w formacie całkowitym (tabela 1). Czasami równocześnie są zapisywane wyniki wstępnej redukcji danych takie jak średnia amplituda, położenia statyczne, estymaty częstotliwości).

Po wstępnym przetwarzaniu, tj. wyrównywaniu surowych danych TOA otrzymujemy pliki nazywane pośrednimi lub sortowanymi, w których wskazania czujników przypisano do poszczególnych łopatek (tabela 2). Jest możliwość bezpośredniego zapisywania pomiarów $\mathrm{w}$ formie matryc wyrównanych danych (posortowanych plików), jednak $\mathrm{w}$ tej strukturze nie możemy rejestrować sygnałów o niskiej jakości, w których występują błędne dane (tzw. nadmiarowe lub brakujące łopatki).

Wstępnie przetworzone dane posortowane są punktem startu do wykonywania transformacji widmowych i wyznaczania parametrów drgań łopatek. Dalsza analiza wymaga wiedzy na temat postaci drgań, rzędowości wymuszeń i zakresów rezonansowych, aby możliwe było poprawne dopasowanie danych z czujników do modelu oscylatora [2]. Ostateczne wyniki analizy są zbiorczo przedstawione w postaci częstotliwości i amplitudy łopatki na wykresie Campbella, który jest podstawą dalszych prac działu konstrukcyjnego.

Pomiarami objęty jest cały czas pracy silnika, zwykle jednak dane zapisuje się we fragmentach, odpowiadającym wykonywanym manewrom. Kolejna zbiór danych (shot) powstaje, gdy prędkość obrotowa na biegu jałowym zostanie osiągnięta (z pewną histerezą). Zbiór obejmuje więc pojedynczy cykl LCF, czyli przejście od prędkości obrotowej biegu jałowego do prędkości startowej i z powrotem (Rys. 2). Zestaw danych jest zazwyczaj przechowywany $w$ osobnym folderze $\mathrm{z}$ automatycznie inkrementowanym licznikiem $\mathrm{w}$ nazwie. Alternatywnie, czas zapisu danych może być stosowany jako unikalna nazwa folderu. 
Tabela 1. Przyklady struktury folderów i konwencje nazewnictwa plików

\begin{tabular}{|c|c|c|c|c|}
\hline & $\begin{array}{c}\text { Rolls-Royce } \\
\text { BTT }\end{array}$ & Hood Tech & ITWL & $\begin{array}{l}\text { ITWL } \\
\text { liczniki }\end{array}$ \\
\hline $\begin{array}{l}\text { Nazwa } \\
\text { folderu }\end{array}$ & Shot001 & 02 oct 2008 & $\begin{array}{l}20.05 .2015 \\
/ 10-42-27\end{array}$ & $\begin{array}{l}09.08 .2014 \\
/ 22-46-15\end{array}$ \\
\hline $\begin{array}{l}\text { surowe dane } \\
\text { TOA }\end{array}$ & $\begin{array}{l}\text { Shot001.001 } \\
\text { Shot001.002 } \\
\text { Shot001.003 } \\
\text { Shot001.004 } \\
\text { Shot001.005 } \\
\text { Shot001.006 } \\
\text { Shot001.007 } \\
\text { Shot001.008 }\end{array}$ & \begin{tabular}{|l|} 
SDFG_1.001 \\
SDFG_1.002 \\
SDFG_1.003 \\
SDFG_1.004 \\
SDFG_1.005 \\
SDFG_1.006
\end{tabular} & $\begin{array}{l}\text { X1-ai0.tdx } \\
\text { X1-ai1.tdx } \\
\text { X1-ai2.tdx } \\
\text { X1-ai3.tdx } \\
\text { X1-ai4.tdx } \\
\text { X1-ai5.tdx } \\
\text { X1-ai6.tdx } \\
\text { X1-ai7.tdx }\end{array}$ & $\begin{array}{l}\text { C1-ctr1.u32 } \\
\text { C1-ctr2.u32 } \\
\text { C1-ctr3.u32 } \\
\text { C1-ctr4.u32 } \\
\text { C1-ctr5.u32 } \\
\text { C1-ctr6.u32 }\end{array}$ \\
\hline raz na obrót & Shot001.009 & \begin{tabular}{|l|} 
SDFG_1.007 \\
\end{tabular} & X1-ai8.tdx & C1-ctr0.u32 \\
\hline format pliku & podwójnie & $\begin{array}{l}\text { int32 bez } \\
\text { znaku }\end{array}$ & double & $\begin{array}{l}\text { int32 bez } \\
\text { znaku }\end{array}$ \\
\hline $\begin{array}{c}\text { kolejność } \\
\text { bajtów }\end{array}$ & Intel & Motorola & $1 \mathrm{II}$ & Intel \\
\hline konfigurac $j$ & $\begin{array}{l}\text { config.cfg } \\
\text { (binarny) }\end{array}$ & \begin{tabular}{|c|}
$\begin{array}{c}\text { SDFG_1.inf } \\
\text { (tekstowy) }\end{array}$ \\
\end{tabular} & $\begin{array}{c}\text { X1.dat } \\
\text { (tekstowy) }\end{array}$ & $\begin{array}{c}\text { C1.dat } \\
\text { (tekstowy) }\end{array}$ \\
\hline
\end{tabular}

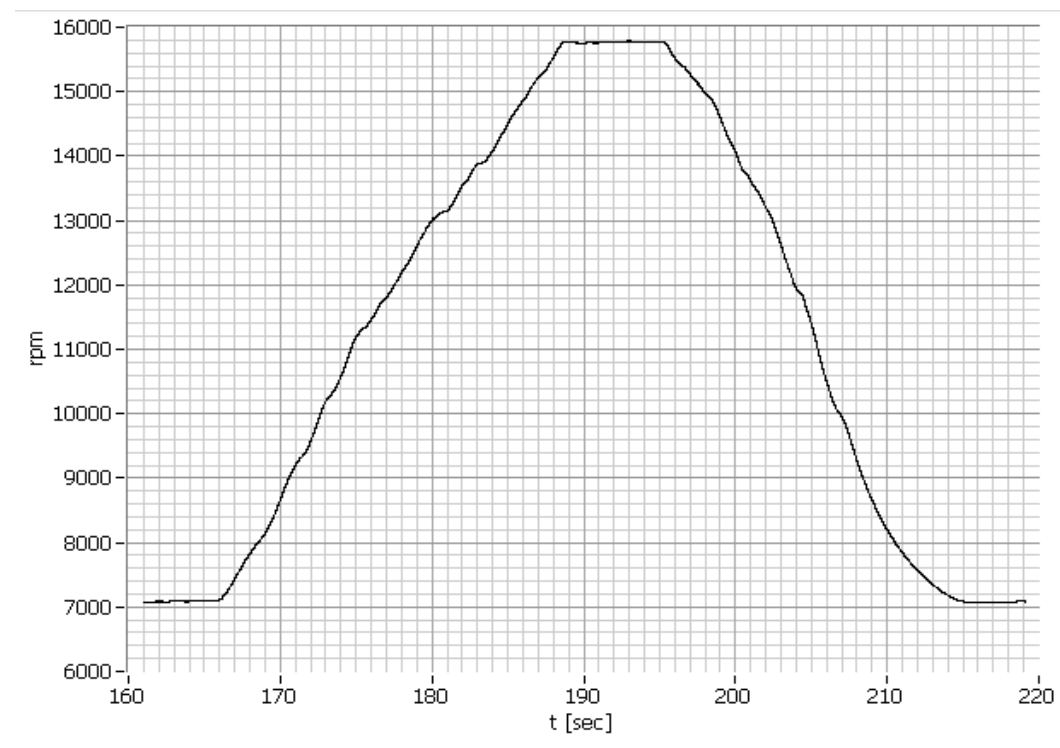

Rys. 2. Cykl LCF - przemiatanie prędkości obrotowej od biegu jałowego do prędkości startowej $i$ z powrotem 
Data management techniques for blade vibration analysis Techniki zarzadzania danymi w analizie drgań topatek

Tabela 2. Przyktad wyrównania (sortowania) surowych danych TOA

\begin{tabular}{|c|c|c|c|}
\hline 1/obr & czujnik 1 & czujnik 2 & Czujnik $n$ \\
\hline$t_{10}$ & $t_{11}$ & $t_{m 2}$ & $t_{m 1 n}$ \\
\hline$t_{20}$ & $t_{21}$ & $t_{12}$ & $t_{m n}$ \\
\hline$t_{30}$ & $t_{31}$ & $t_{22}$ & $t_{1 n}$ \\
\hline$t_{40}$ & $t_{41}$ & $t_{32}$ & $t_{2 n}$ \\
\hline$t_{50}$ & $t_{51}$ & $t_{42}$ & $t_{3 n}$ \\
\hline$t_{60}$ & $t_{61}$ & $t_{52}$ & $t_{4 n}$ \\
\hline$T_{-70}$ & $t_{71}$ & $t_{-62}$ & $t_{5 n}$ \\
\hline$t_{80}$ & $t_{81}$ & $t_{-72}$ & $t_{6 n}$ \\
\hline$t_{90}$ & $t_{91}$ & $t_{82}$ & $t_{7 N}$ \\
\hline
\end{tabular}

\begin{tabular}{|l|l|l|l|}
\hline nóż\# & $\begin{array}{l}\text { Czujnik } \\
1\end{array}$ & $\begin{array}{l}\text { Czujnik } \\
2\end{array}$ & $\begin{array}{l}\text { Czujnik } \\
n\end{array}$ \\
\hline 1 & $\delta_{11}$ & $\delta_{12}$ & $\delta_{13}$ \\
\hline 2 & $\delta_{21}$ & $\delta_{22}$ & $\delta_{23}$ \\
\hline 3 & $\delta_{31}$ & $\delta_{32}$ & $\delta_{33}$ \\
\hline & & & \\
\hline $\mathrm{m}-1$ & $\delta_{\mathrm{m}-1,1}$ & $\delta_{\mathrm{m}-1,2}$ & $\delta_{\mathrm{m}-1,3}$ \\
\hline $\mathrm{m}$ & $\delta_{\mathrm{m} 1}$ & $\delta_{\mathrm{m} 2}$ & $\delta_{\mathrm{m} 3}$ \\
\hline
\end{tabular}

Wyników analizy nie przechowuje się w jednym katalogu z danymi, ale tworzy się podkatalog lub równoległe drzewo katalogów w innej lokalizacji. Kolejne próby analizy nie powinny nadpisywać poprzednich, więc stosuje się unikalne nazwy folderów zawierające czas lub kolejny numer.

Gdy stosowane są różne formaty i konwencje nazewnictwa plików, konieczna jest konwersja plików, aby możliwa była analiza drgań łopatek przy użyciu innego pakietu. Od kilku lat działa grupa robocza, która próbuje uzgodnić wspólny format danych [1], aby możliwa była wymiana plików we wspólnych próbach silników.

\section{Typowe metody wizualizacji}

Wzorzec położeń statycznych

Statyczne położenia łopatek na obwodzie lub podziałki międzyłopatkowe są używane do identyfikacji stopnia oraz weryfikacji numerowania łopatek i podanych położeń obwodowych czujników, aby właściwie wyrównać (posortować) dane TOA pochodzące $\mathrm{z}$ różnych czujników. Wzorzec położeń statycznych łopatek(Rys. 3) jest odciskiem palca palisady łopatek i może być także wykorzystywany jako odniesienie $\mathrm{w}$ układzie wirującym oraz $\mathrm{w}$ monitorowania stanu technicznego łopatek tj. do wykrywania pęknięć lub uszkodzeń pochodzących od ciał obcych (FOD). 
Przbieg drgań - Blade Waterfall

Podstawowym sposobem zobrazowania danych wejściowych jest wyświetlenie przebiegu przeskalowanych odkształceń łopatek dla wybranego czujnika w kolejnych obrotach lub w funkcji czasu, pozbawionych składowej stałej (Rys. 4).Wykres obrazuje wzmocniony sygnał odkształcenia wierzchołka dla kolejnych łopatek, z pierwszą łopatką na dole.

$\mathrm{Na}$ wykresie można wykreślić odchylenia wierzchołka od położenia równowagi w funkcji numeru obrotu lub czasu lub prędkości obrotowej, aby sprawdzić jakość sygnału od czujników lub wskazać łopatki, których odpowiedź na wymuszenie różni się od innych (tzw. łopatki mocno odpowiadające). Gdy prędkość jest zmieniana jest możliwe, aby zgrubnie ustalić częstotliwość rezonansową łopatek dla postaci drgań niskiego rzędu.

Po zerowaniu [10] i dopasowaniu danych z kilku czujników do modelu oscylatora metodą najmniejszych kwadratów [2] możliwe jest wykonanie wykresu pozbawionej aliasingu amplitudy, a nawet zobrazowanie fazy drgań kolorem [6].

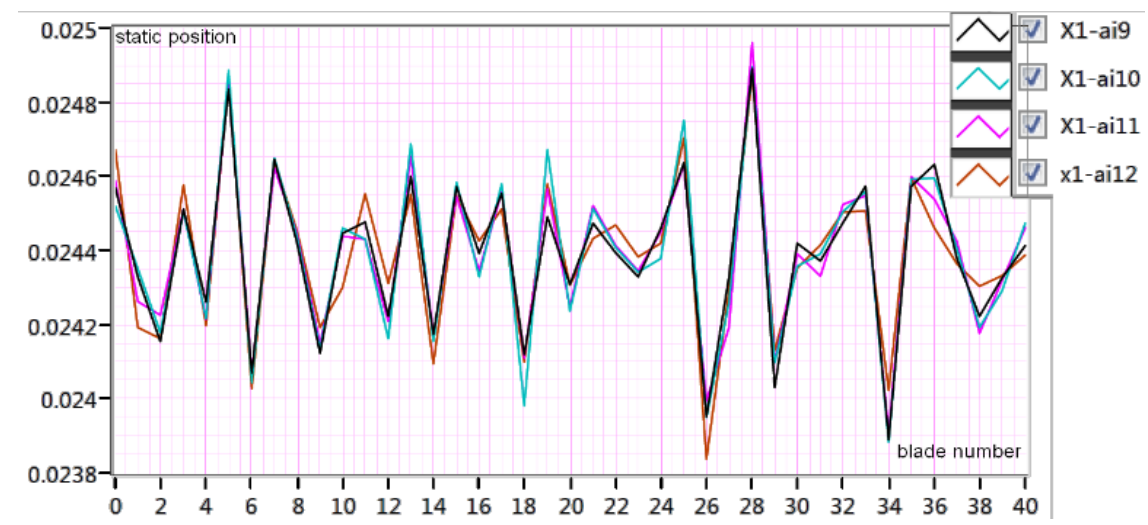

Rys. 3. Przykład wzorca położeń statycznych (4 czujniki)

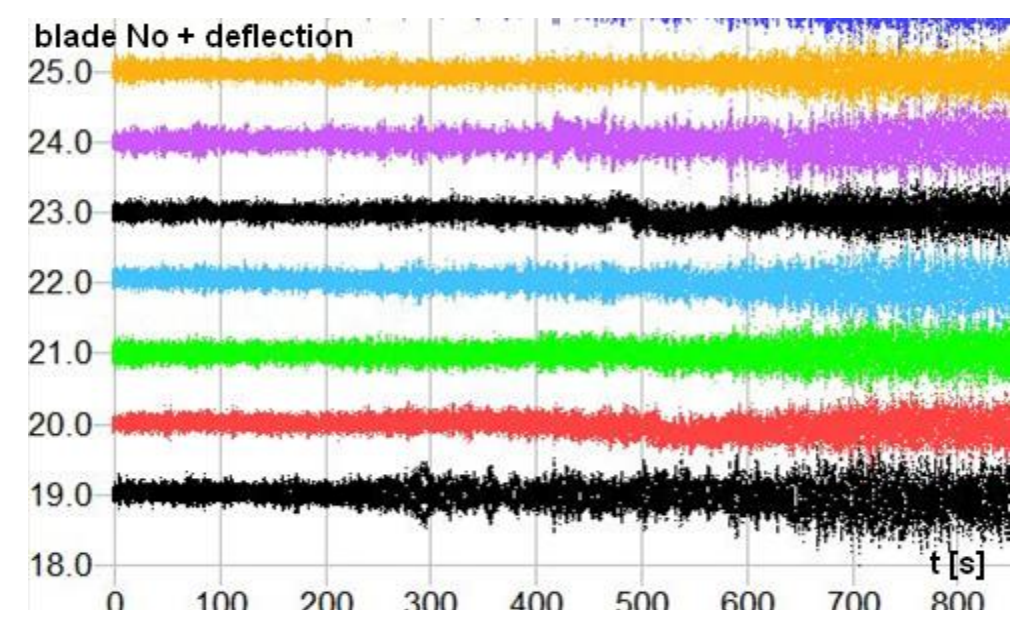

Rys. 4. Przyktad wykresu przebiegu drgań topatek 
Data management techniques for blade vibration analysis Techniki zarzadzania danymi w analizie drgań topatek

Widmo pojedynczej łopatki

Drgania pojedynczych łopatek w kolejnych obrotach mogą być analizowane w dziedzinie częstotliwości za pomocą szybkiej transformaty Fouriera. Wykres przedstawia zmianę widmowej gęstości mocy odchylenia wybranej łopatki w skali logarytmicznej podczas zmniejszenia prędkości wirnika w paśmie od 0 do połowy prędkości obrotowej (1/2 EO) (rys.5). Można w ten sposób zmierzyć ułamkową częstotliwość i amplitudę drgań asynchronicznych. Spektrogramy mogą być generowane nawet on-line, biorąc kolejno pomiary odchylania łopatki z kilku obrotów do okna FFT.

Dla danych pochodzących z jednego czujnika pasmo jest ograniczone do połowy częstotliwości obrotowej ( $1 \frac{1}{2}$ EO). Wszelkie składniki o wyższych częstotliwościach są przedstawiane jako aliasy, więc widmo wymaga rekonstrukcji, aby zmierzyć rzeczywistą częstotliwość drgań łopatki. Wygodnie jest wykonać wykres w funkcji obrotów zamiast funkcji czasu i rzędowości wymuszenia zamiast częstotliwości na osi y, gdyż uzyskuje się wtedy stałą rozdzielczość widma.

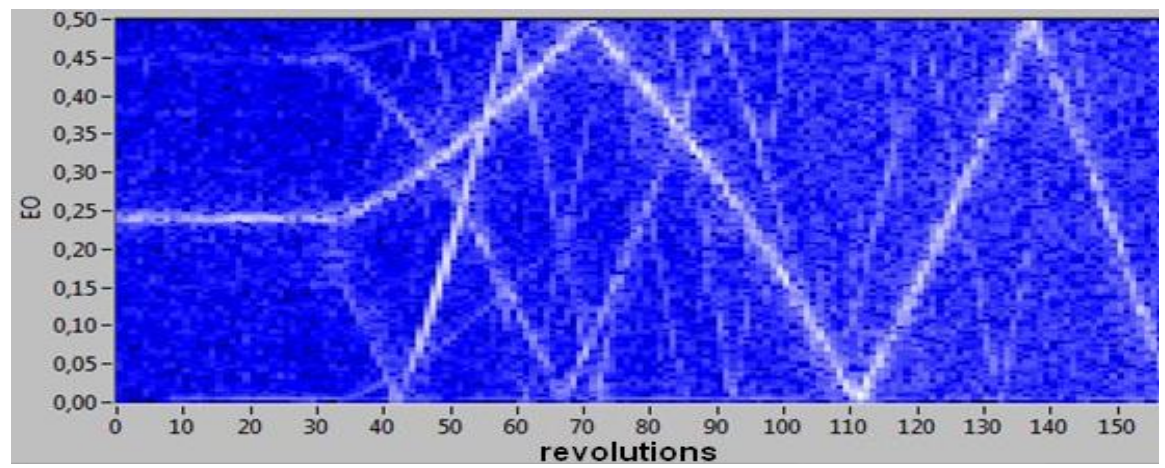

Rys. 5. Przykład widma pojedynczej topatki

Wykres fali biegnącej (widmo wszystkich łopatek)

Drgania asynchroniczne, takich jak flatter, wirująca strefa oderwań lub pompaż obejmują nie tylko pojedyncze łopatki, ale cały wieniec i z tego powodu widmo wszystkich łopatek jest korzystnym sposobem ich wizualizacji (Rys. 6).Gdy ugięcia wszystkich łopatek są przetwarzane razem, częstotliwość próbkowania mnożona jest przez liczbę łopatek $b$, więc szerokość pasma jest równa $1 \frac{1}{2} \mathrm{EO} b$.

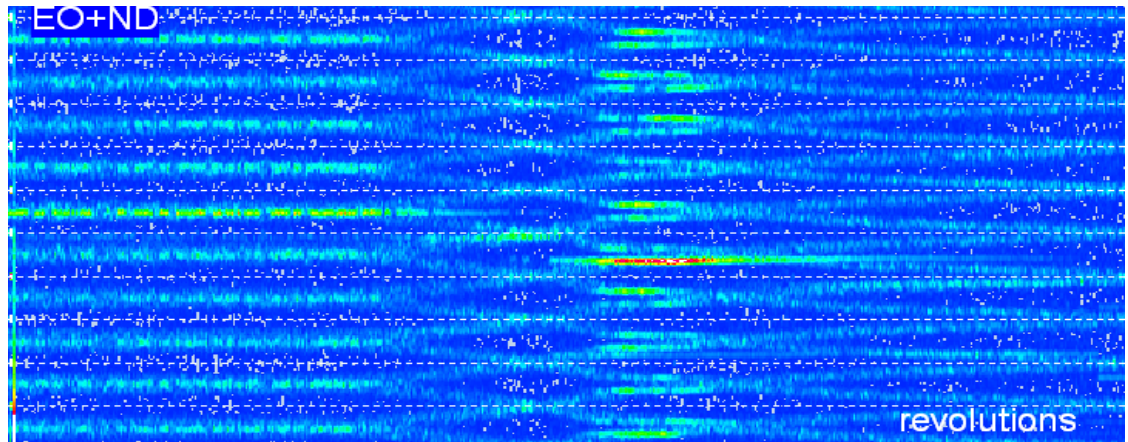

Rys. 6. Przyktad widma wszystkich topatek 
Diagram Campbella

Wykres Campbella jest ostateczną formą prezentacji parametrów drgań wymuszonych, przedstawiając drgania pojedynczych łopatek lub ułopatkowanej tarczy pobudzone przez: 1) rzędowości prędkości obrotowej (drgania synchroniczne) lub 2) siły związanych z przepływem (drgania asynchroniczne). Amplituda i częstotliwość drgań jest przedstawiona zbiorczo w funkcji prędkości obrotowej w odniesieniu do rzędowości wymuszenia.

\section{Narzędzia analityczne ogólnego użytku}

$\mathrm{W}$ związku $\mathrm{z}$ odpowiedzialnością związaną $\mathrm{z}$ prowadzeniem prac na rzecz lotnictwa oraz wymogami prawnymi zależy nam, by wykonywane analizy składały się $\mathrm{z}$ operacji, które są udokumentowane. Ważne jest, by opracowywany i archiwizowany był nie tylko raport, ale również kody źródłowe i wykorzystywane dane. Warto wyeliminować ręczne operacje i zastąpić je programawmi, by zmniejszyć wpływ czynnika ludzkiego na wyniki. Bardzo rzadko wykonuje się działanie jednokrotnie, więc prawie zawsze opłaca się napisać program lub skrypt.

Staramy się uniknąc zastrzeżonych formatów plików, gdyż dostęp i zarządzanie danymi $w$ formacie tekstowym lub otwartym jest łatwiejsze i nie wymaga specjalnego oprogramowania. W związku z tym preferujemy pliki danych i kod źródłowy $\mathrm{w}$ formacie tekstowym. Jeśli trzeba zaoszczędzić miejsce na dysku i stosujemy pliki binarne, używamy otwartych formatów lub plików raw z tekstowym nagłówkiem w oddzielnym pliku.

Aby możliwe było powtórzenie analizy w końcowej wersji jak również jej wcześniejszych prób, wykorzystujemy śledzenie wersji konfiguracji pomiarowej, kodu źródłowego i archiwizujemy dane i bibliotek niezbędnych do uruchamiania kodu.

Do przetwarzania sygnałów pomiarowych stosujemy języki programowania wysokiego poziomu takie jak LabView i Matlab, które wyposażowno w narzędzia do operacji na próbkowanych sygnałach i tworzenia wykresów. LabView (podobnie jak Matlab) posiada bogatą bibliotekę procedur numerycznych i sprawnie przetwarza duże macierze, a ponadto dobrze obsługuje systemy pomiarowe. Graficzny język uniemożliwia iteraktywną prace w konsoli tak jak w Matlab i innych jezykach interpretowanych. Mimo wszystko możliwe jest szybkie prototypowanie algorytmów, ponieważ nie jest trudne stworzenie programu ze standardowym interfejsem graficznym, według najprostszego wzorca Immediate SubVi. Graficzny kod źródłowy i binarny format plików vi utrudnia jednak śledzenie wersji kodu i przetwarzanie wsadowe. Ze względu na brak konsoli, trudne jest rejestrowanie interaktywnej pracy w sposób podobny do Matlab i innych języków interpretowanych. Pomimo tego wygodne jest szybkie prototypowanie algorytmów w LabView, ponieważ stworzenie programu ze standardowym interfejsem graficznym $\mathrm{z}$ wykorzystaniem najprostszego wzorca projektowego Immediate SubVi nie wymaga wysiłku. 
Data management techniques for blade vibration analysis

Techniki zarzadzania danymi w analizie drgań topatek

Napisanie większego programu w LabView jest równie złożone jak w przypadku innych narzędzi i wymaga zastosowania zaawansowanych technik i wzorców projektowych, takich jak maszyny stanu, kolejki i pętle zdarzeń [15]. Do integracji $\mathrm{w}$ większy program prototypowych podprogramów potrzebna jest dobra znajomości pakietu. Nie mniej jednak, LabVIEW wraz z systemem pomiarowym PXI tworzą zestaw dobrze skrojonych narzędzi do tworzenia skalowalnych i elastycznych rozwiązań do akwizycji oraz analizy danych w czasie rzeczywistym [4]. Mimo wszystko to Matlab należy uznać za referencyjne środowisko do analiz badawczych ze względu na:

- możliwość wczytywania danych w różnych formatach,

- operowanie na całych kanałach i macierzach (w odróżnieniu od Excel),

- możliwość pracy interaktywnej, a następnie zbudowania skryptów na podstawie historii poleceń i szybkie przejście do przetwarzania wsadowego,

- wygodny dostęp do wyników pośrednich w przestrzeni roboczej w postaci tabel i na wykresów,

- bogate narzędzia do wizualizacji danych.

Wymienione funkcje można znaleźć w pakiecie NI Diadem, promowanym jako narzędzie do zarządzania danymi i zautomatyzowanego generowania wykresów. Program oferuje wygodny dostęp do danych z wielu źródeł, wygodny graficzny interfejs użytkownika oraz szablony wykresów .tdv i raportów .tdr, które można używać wielokrotnie do nowych zestawów danych. Mimo wszystko to jednak język Matlab jest standardem w obliczeniach naukowych, ma bogate biblioteki, wiele rozwiązań $\mathrm{z}$ otwartym kodem i dużą społecznośc użytkowników w odróżnieniu od niewygodnego języka VBA wbudowanego w Diadem.

Złożone biblioteki do tworzenia raportów w formatach html, pdf, doc są dostępne w Matlab i LabView. W praktyce raporty generowane w wymienionych formatach nie spełniały naszych oczekiwań: html nie nadawał się do publikacji, do pdf trudno wprowadzić zmiany, a pliki doc wymagały zbyt wielu ręcznych poprawek.

MATLAB oferuje co najmniej dwa sposoby generowania raportów: potężny Report Generator Toolbox i łatwiejsza w użyciu wbudowana funkcja publish. Oba mechanizmy umożliwiają dostosowywanie stylu raportu przy użyciu arkuszy stylów / szablonów. Funkcja publish uruchamia automatyczny generator raportów, który tworzy dokument w wybranym formacie (HTML, XML, LaTeX, doc, ppt, pdf) oparty na kodzie, wynikach skryptu, poleceniach języka znaczników i komentarzach w kodzie.

Wykorzystanie MS Office w procesie analizy danych badawczych nie jest najlepszym pomysłem, ponieważ technologie Microsoft, takie jak ActiveX i VBA są przestarzałe i ich działanie zmienia się w kolejnych wersjach pakietu w sposób nieoczekiwany. Skrypty VBA trzeba uruchamiać często metodą prób i błędów i nie można ustalić przyczyn istniejących problemów.

Jeśli zależy nam na przejrzystości i integralności kodu oraz możliwości wyjaśnienia przyczyn błędnego działania lepiej jest unikać programów i bibliotek, których działanie jest słabo udokumentowane. 
Z tych powodów oprogramowanie otwarte lepiej nadaje się do zastosowań naukowych i badawczych. Bogate możliwości pakietów komercyjnych trudno wykorzystać, jeśli nie kontrolujemy wykonywanych przez nie działań. Nauczenie się zaawansowanych możliwości programów wymaga czasu i wysiłku i lepiej je poświęcić na projekty otwarte, które będziemy mogli rozwijać i dostosować do swoich potrzeb.

Python to jedna $\mathrm{z}$ najlepszych alternatyw Matlaba. To nowoczesny język obiektowy wysokiego poziomu i ogólnego przeznaczenia, $\mathrm{z}$ otwartymi bibliotekami naukowymi o dużych możliwościach (NumPy, scipy, matplotlib, Pandas) oraz dużą społecznością użytkowników i obfitością dostępnej dokumentacji, materiałów edukacyjnych i przykładowego kodu [16], [17]. Może być instalowany na większości systemów operacyjnych, najlepiej $\mathrm{w}$ formie dystrybucji naukowej. Zalecane jest również pobranie wybranych narzędzi pomocniczych, takich jak oprogramowanie kontroli wersji Git.

Składnia języka Python różni się od Matlab, ponieważ został on zaprojektowany w celu uzyskania maksymalnej czytelności i elastyczności. Ekosystem zbudowany wokół Python może zastapić Matlab w większości zastosowań, jednocześnie oferując wiele nowych możliwości niedostępnych w nim. Wymienione biblioteki naukowe oraz środowisko IDE Spyder (zintegrowane środowisko programistyczne) przypominają Matlab, dzięki czemu można rozpocząć pracę w krótkim czasie, jeśli mamy podstawowe umiejętności programowania w Pythonie.

\section{Biblioteka Report Generation Framework}

Raporty pisane w ITWL mogą mieć różną postać w zależności od opisywanego problemu, odbiorcy i wykorzystywanych narzędzi. Zwykle jednak część główna zawiera najważniejsze fakty i podsumowanie, natomiast wyniki szczegółowo prezentowane są $\mathrm{w}$ załącznikach. Poszukiwaliśmy narzędzia wspomagającego przygotowania załączników, który zwykle składają się z wprowadzenia i sekwencji ponumerowanych i podpisanych wykresów.

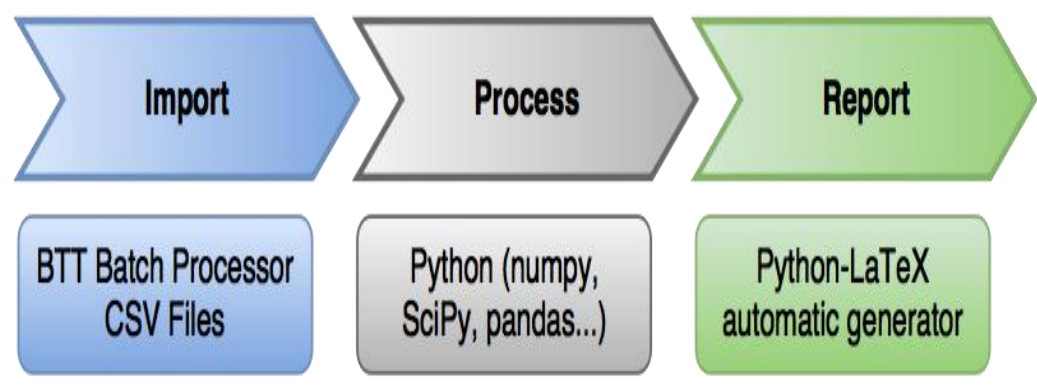

Rys. 7. Uproszczony schemat przeptywu danych przy analizie drgań topatek i generowaniu raportów z wykorzystaniem Pythona, RGF \& Batch Processor 
Data management techniques for blade vibration analysis

Techniki zarzadzania danymi w analizie drgań topatek

Zdecydowaliśmy się połączyć obecnie dostępne narzędzia wspierające przetwarzanie i publikowanie wyników analiz drgań łopatek(rys. 7). LaTeX to dojrzałe profesjonalne środowisko do zautomatyzowanego składu tekstu, podatne na maszynową generację plików źródłowych i ich manipulację dzięki swojemu językowi znaczników.

Język programowania Python wraz ze swoim ekosystem jest w stanie rozwiązać zarówno zadania automatyzacji jak i analizy danych. Te dwa mogą być łączone ze sobą oraz z oprogramowaniem do kontroli wersji (git / gitlab), środowiskami wirtualnymi Pythona i IPython Notebooks w celu zapewnienia identyfikowalności i powtarzalności analiz.

\section{Pomyst i struktura projektu}

RGF, choć nazwany słowem "framework" na początku projektu, to raczej zestaw narzędzi i bibliotek (Rys. 8). Jego najważniejszym elementem jest moduł Pythona RGF.render, odpowiedzialny za automatyczne generowanie wyklesów, tabel i kodu źródłowego tex. Jego główne założenia projektowe to:

- Luźna zależność RGF od reszty środowiska Pythona. Renderowanie jest niezależne od źródła danych i obliczeń i opiera się na konwencji dynamicznych kontenerów danych i definicji wykresów przekazywanych do automatycznego silnika renderowania. Wymagania odnośnie struktury danych źródłowych ograniczono do minimum, sięgając do ich elementów na zasadzie badania atrybutów udostępnionych przez obiekt (duck typing).

- Odgrywa rolę (w określonych miejscach) przezroczystej nakładki wokół istniejących bibliotek, aby zapewnić większość funkcji bazowych i uniknąć wyważania otwartych drzwi. Na przykład wszystkie dostępne parametry kreślenia matplotlib mogą być (opcjonalnie) określone w definicji wykresu, czy też arbitralne parametry mogą być przekazywane do Jinja2 w ramach przetwarzania szablonu.

- Dodatkowe zadania formatowania i generowania podpisów mogą być realizowane w dobudowanych obiektach (funkcje, metody, klasy) przekazywanych do automatycznego silnika renderowania w czasie wykonywania, spełniając zasadę odwrócenia sterowania.

Moduł Render ma wysoką spójność i jego składniki są otwarte na rozszerzenie przez podstawienie obiektu lub dziedziczenie / dekorację, co zachęca do wielokrotnego wykorzystywania kodu. Sam kod modułu również wykorzystuje ponownie zasoby istniejące w bibliotekach Pythona.

Matplotlib jest de facto standardową biblioteką języka Python do kreślenia wykresów o jakości odpowiedniej dla publikacji. Chociaż jest bogata w funkcje i zorientowana obiektowo, to umożliwia wykonanie złożonych wykresów w prosty sposób, udostępniając proceduralne API, podobne do składni Matlaba .

Jinja2 jest silnikiem szablonów (podobnym do silnika szablonów Django) zapewniającym konfigurowalną składnię i łatwość debugowania. Podstawowy 
przykład szablonu LaTeXa mieści się w około 20 liniach kodu Pythona, z których większość stanowi definicja składni. Wstawienie zbioru rysunków do szablonu może być tak proste jak pojedyncza pętla for działająca na liście wykresów.

Szablony dla popularnych typów raportów i prezentacji wykorzystywanych w ITWL zostały opracowane w postaci plików *.tex.

LaTex dostarcza narzędzia do generowania złożonych publikacji wysokiej jakości: tworzenia tabel, wykresów, automatycznych list i indeksów, numeracji stron, numerowania podpisów, referencji itp. z zachowaniem edytowalnego formatu pliku tekstowego po renderingu i prostej struktury szablonu.

Wygenerowany kod źródłowy *.tex może być modyfikowany w TeXstudio lub innym edytorze w celu dodania akapitów, nietypowych schematów lub edycji podpisów. Zmiany w plikach Tex mogą być łatwo śledzone z wykorzystaniem systemu kontroli wersji. Git może być również używany do łączenia różnych wersji tekstu (kodu) opracowanych przez różnych użytkowników.

Silnikowi renderowania mogą towarzyszyć dodatkowe moduły realizujące wstępne przetwarzanie danych. Na przykład, moduł 'readbtt "został stworzony, aby wspierać bezproblemowe ładowanie plików wynikówych Rolls Royce BTT Batch Processor [9] wraz ze zbieraniem metadanych oraz zapewnieniem dedykowanego sposobu formatowania i tworzenia podpisów.Należy dodać, że funkcje readbbt dotyczące metadanych są praktycznie niezależne od renderowania i są również używane oddzielnie.

\section{Przetwarzanie wsadowe}

Funkcje języka Python i biblioteki RGF, takie jak przetwarzanie napisów, wyrażenia regularne i listy umożliwiają przetwarzanie wsadowe całego drzewa katalogów w jednym krótkim skrypcie. RGF umożliwia wybór danych z kilku plików i generowanie wykresów przeglądowych. W typowym scenariuszu kolejne cykle LFC są przechowywane w oddzielnych zestawach danych (Rys. 9) i konieczne jest zobrazowanie zachodzących zmian odpowiedzi łopatki.

Alternatywnie można zdefiniować program przetwarzania wsadowego bez modyfikacji skryptu bazowego. Lista plików wejściowych, serii danych i definicji wykresów może być dostarczona w postaci pliku YAML w formacie czytelnym dla człowieka (tabela 3). Dla modułu RGF.render nie ma znaczenia czy wymagane struktury zostały określone statycznie czy skonstruowane w locie.

Zewnętrzne narzędzia (z ekosystemu Unix lub Windows), w tym oprogramowanie komercyjne mogą być wywołane z kodu Pythona za pomocą parametrów wiersza poleceń lub poprzez API zgodne z DLL lub ActiveX. Alternatywnie polecenie Unix "make" może być wykorzystane do przeprowadzenia złożonych analiz, zrealizowanych $\mathrm{w}$ programach napisanych $\mathrm{w}$ językach kompilowanych $(\mathrm{C}++$, Fortran), łączonych z kodem Pythona i LateXa. 


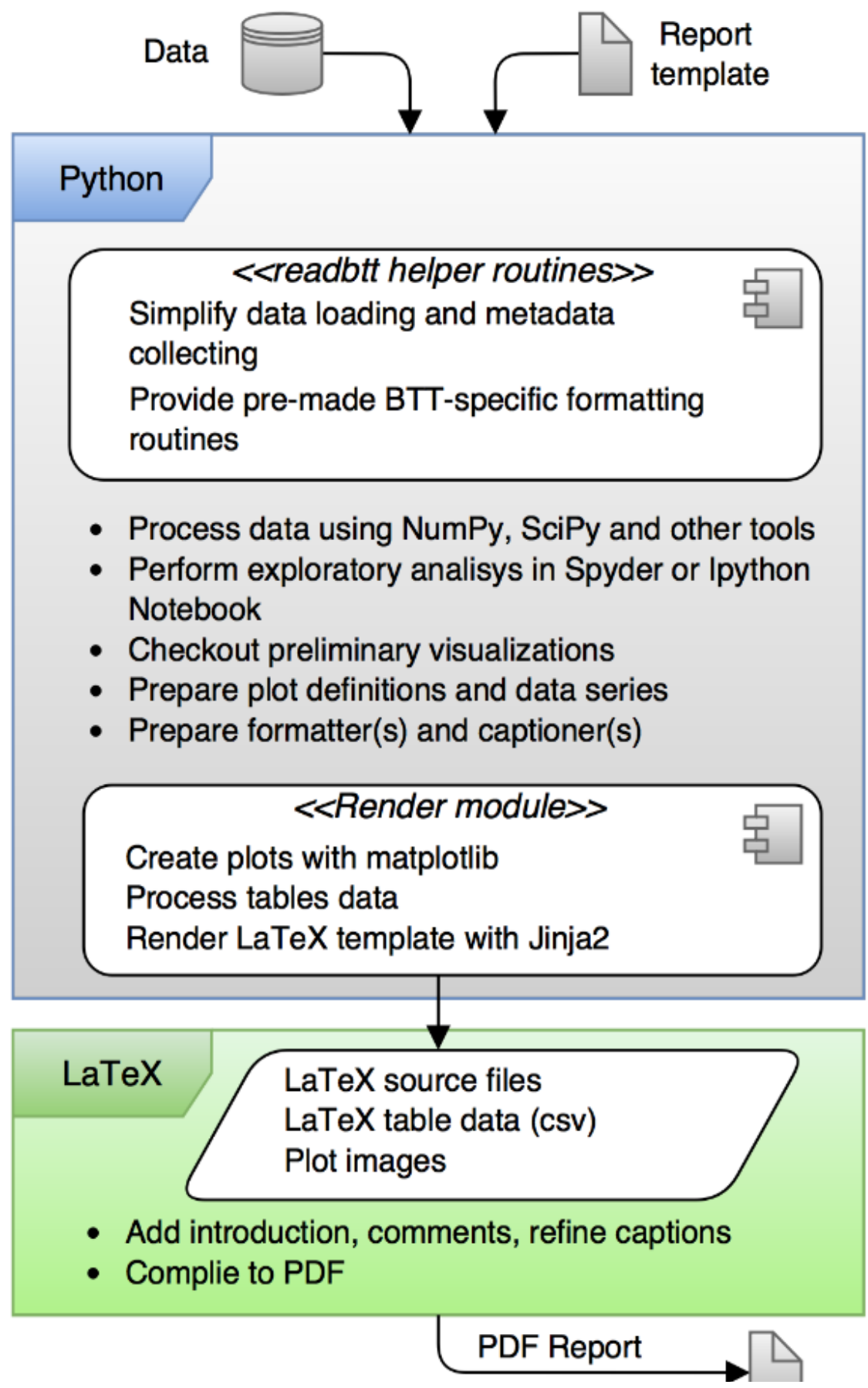

Rys. 8. Schemat blokowy generowania raportu $w$ formacie $p d f i$ tex 


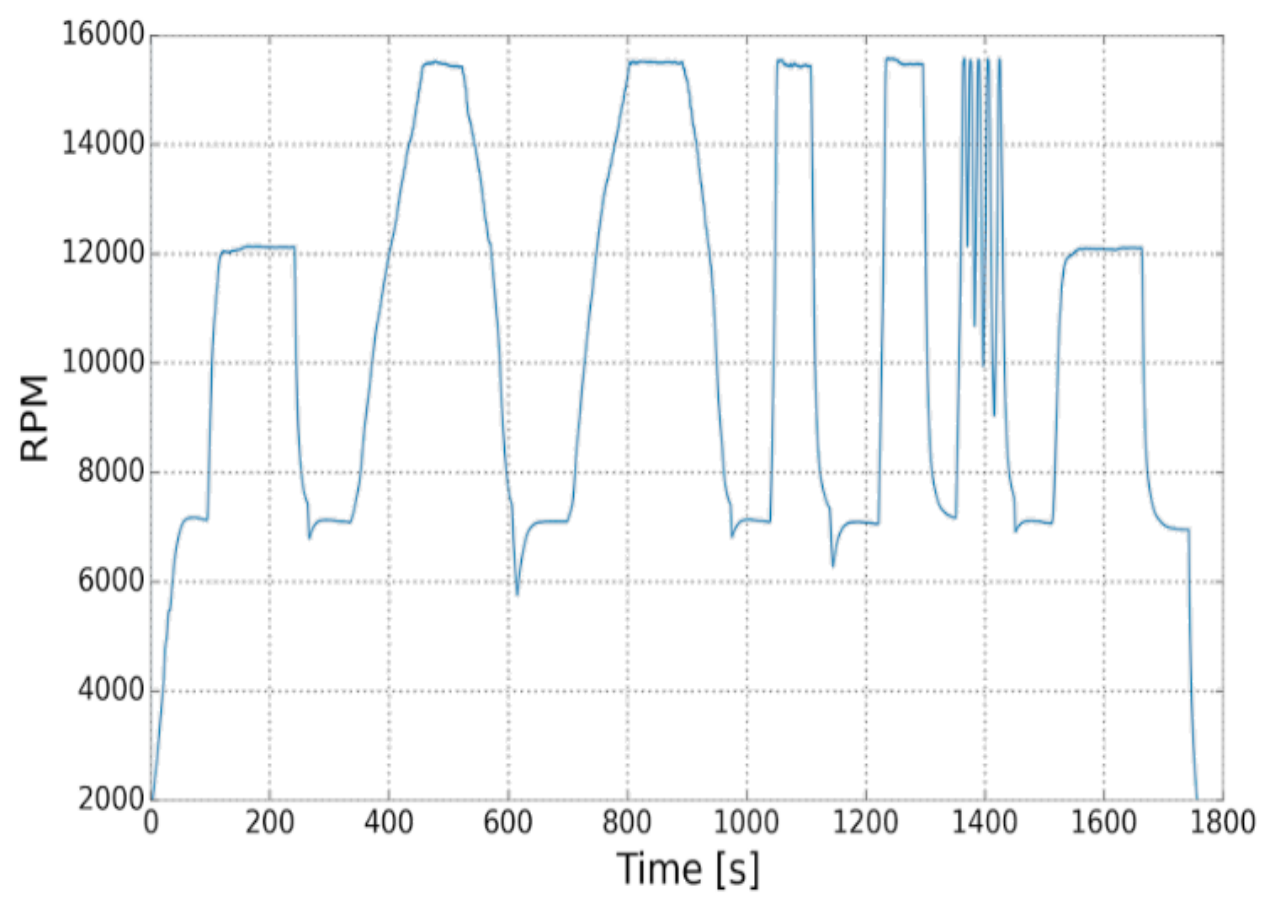

Rys. 9.Przyktad profilu próby silnika

Tabela 3. Przykład pliku wsadowego w formacie YAML

readfiles:
file4: /home/Shot001 E009 M2 9077 to 9988 RPM Full1.csv
file5: /home/Shot001 E003 M1 7997 to 10202 RPM Summary1.csv
file6: /home/Shot001 E003 M1 10202 to 7997 RPM Summary2.csv
figures:
- - - [ file5, blade, freq, \{smooth: True, fig: \{figsize: [10, 5]\}\}]
- [ file5, blade, freq, \{kwargs: \{linestyle: ", marker: '.'\}\}]
- - - [ file5, blade, freq, \{plottype: bar, fig: \{figsize: [10, 5]\}, kwargs: \{label: file1\}\}]
- [ file6, blade, freq, \{plottype: bar, kwargs: \{color: r, width: 0.4, label: file2\}\}]
- - - [ file4, time_sec, speed_rpm, \{fig: \{figsize: [10, 12.5]\}, kwargs: \{label: 'RPM(Time)'\}\}]
- - [ file4, speed_rpm, blade_01_mm_pp, \{kwargs: \{label: 'Blade 1'\}\}]

Prezentowane podejście, oparte na plikach $\mathrm{w}$ formacie tekstowym objętych systemem kontroli wersji, umożliwia tworzenie analiz w formie dokumentów o wysokiej jakości składu, które można łatwo wygenerować powtórnie. 
Data management techniques for blade vibration analysis

Techniki zarzadzania danymi w analizie drgań topatek

\section{Interaktywna analiza danych}

Języki interpretowane zapewniają łatwy, bezpośredni dostęp do wyników działań składających się na proces analizy danych, umożliwiając rzeczywistą interakcję badacza $\mathrm{z}$ danymi. $\mathrm{Z}$ drugiej strony, aby odtworzyć procedurę przetwarzania danych wymagane jest śledzenie poszczególnych jej kroków. Śledzenie to umożliwia również dokumentację samej implementacji analizy. Ipython jest powłoką Pythona posiadającą szereg ulepszeń ułatwiających pracę interaktywną, m.in. zapisywanie historii (również $\mathrm{z}$ wielu sesji) oraz jej eksport do skryptu. Ipython jest również wbudowany w głównym oknie Spyder IDE, więc można $\mathrm{z}$ nich korzystać w programowaniu oddolnym (buttom-up), rozbudowująć sekwencję poleceń powłoki $\mathrm{w}$ zaawansowane funkcje i moduły, jednocześnie mając możliwość debugowania kodu i wyświetlania wyników pośrednich. W związku z tym, można prowadzić eksplorację danych i krok po kroku opracowawywać nowe modele i metody przetwarzania.

Istnieje wiele przydatnych modułów Pythona, które umożliwiają między innymi:

- Dostęp do innych formatów danych, baz danych czy interfejsów sieciowych,

- Obliczenia numeryczne i operacje statystyczne na całych kanałach (tablicach) z wykorzystaniem NumPy, SciPy i pandas,

- Interakcje z systemem operacyjnym i urządzeniami wejścia/wyjścia.

Innym potężnym środowiskiem do interaktywnych obliczeń naukowych i analizy danych są IPython Notebooks, które łączą instrukcje Pythona, ich wyniki oraz komentarze w dostępny w czasie rzeczywistym interaktywny dokument [16], [18].Funkcjonalność przetwarzania danych i generowania wykresów zaimplementowana w RGF lub innym kodzie Pythona może być wykorzystywana bezpośrednio z komórek Notebooka (Rys.10).Instrukcje w ich komórkach są wykonywane na żądanie i nowe wyniki są wyświetlane natychmiast, dzięki czemu analiza może być wykonywana i dokumentowana krok po kroku. Podobne narzędzia tworzenia raportów dostępne w środowisku Matlaba generują dokumenty statyczne (publish) lub zależą od technologii firmy Microsoft (Matlab Notebook w MS Word).

RGF wprowadza kolejny zestaw narzędzi do wewnętrznego zestawu narzędzi organizacji. Może to być niepożądane, szczególnie gdy istnieje silna zależność od już istniejących rozwiązań i ani Python ani LaTex nie jest używany. Nawet używając Pythona, w niektórych przypadkach bardziej efektywne może być bezpośrednie generowanie wykresów, bez użycia RGF. Ponadto, użytkownicy muszą być zaznajomieni $\mathrm{z}$ programowaniem $\mathrm{w}$ Python i podstawowymi narzędziami systemu Unix, aby móc korzystać efektywnie z RGF. Oprócz tego, w ekosystemie Python / LaTeX może brakować specyficznych funkcji, oferowanych przez oprogramowanie komercyjne. 


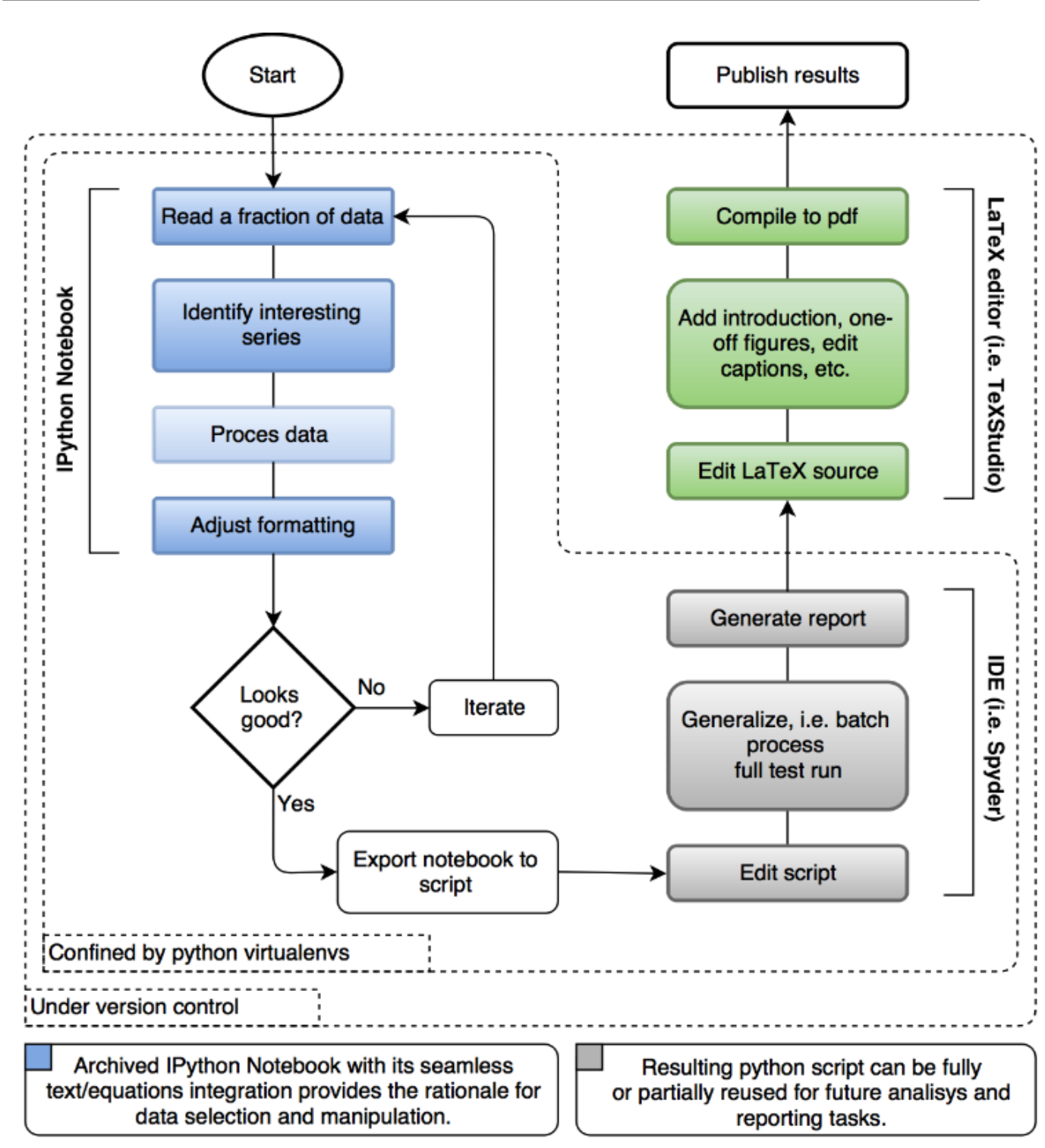

Rys. 10. Interaktywna analiza danych w ekosystemie Pythona i RGF

\section{Przykladowe wyniki}

RGF i Ipython notebook został wykorzystany do wizualizacji wybranych wyników analizy drgań łopatek wykonanej w BTT Batch Processor dla rezonansu M2 EO7. Zaimportowano pliki CSV: Full (Rys. 11) oraz Summary (Rys. 12) [9]. Patrząc na wykres fazowy można sprawdzić, czy Batch Processor poprawnie zidentyfikował rezonans (Rys. $11 \mathrm{c}$ ). 
Data management techniques for blade vibration analysis Techniki zarzadzania danymi w analizie drgań topatek

a)

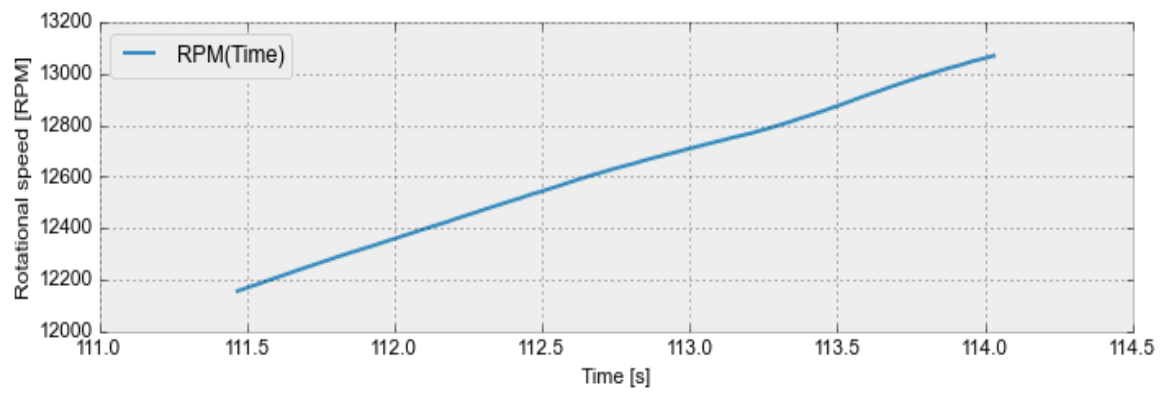

b) $\overline{\underline{\varepsilon}} 0.35$

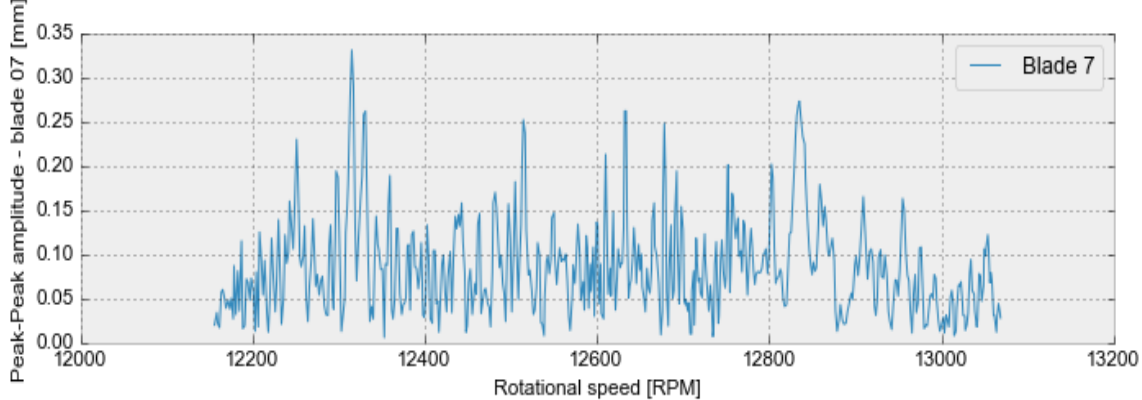

c)

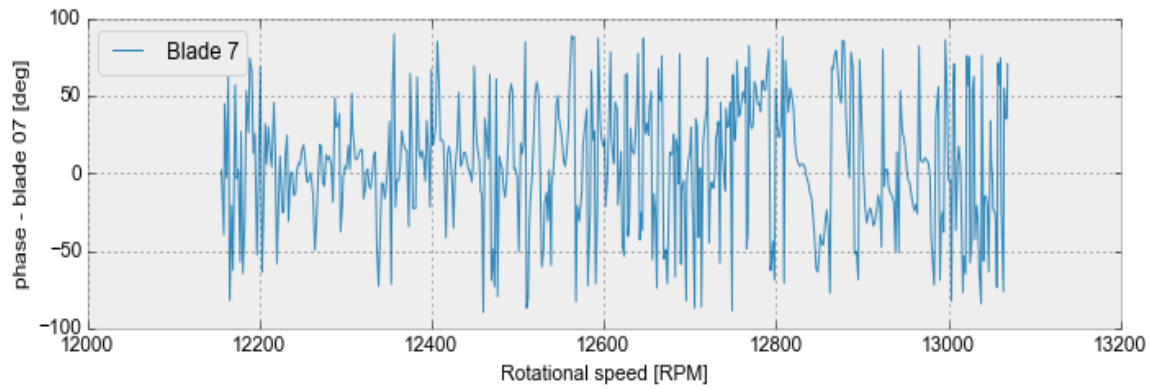

d)

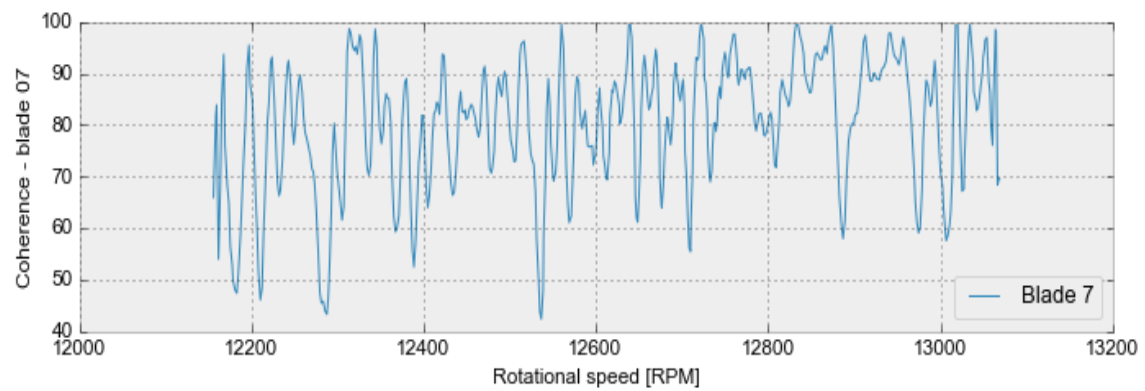

Rys. 11 .Skanowanie rezonansu M2 EO7:

a) prędkość obrotowa, b) amplituda, c) faza oraz d) zbieżność 

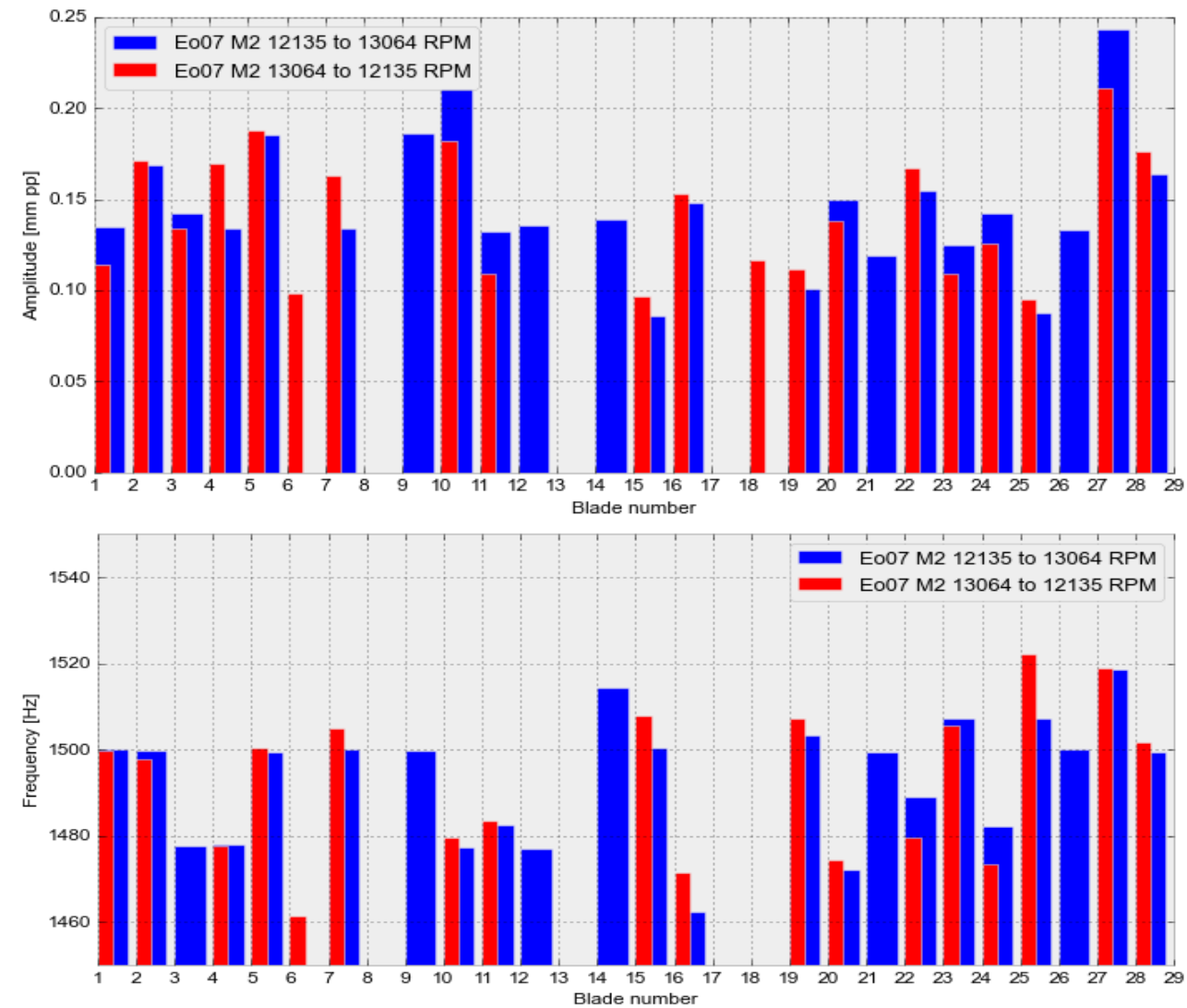

Rys. 12. Amplitude and frequency of M2 EO7 resonance

\section{Podziękowania}

Badania byly finansowane przez rzad polski w latach 2012-2014; Umowa nr PBS1 / B4 / 5/2012.

\section{Literatura}

[1] B. Hayes (chair) "ANSI/ISA-107.1-2013 Industry Standard File Format for Revolution-Based, Tip Timing Data", www.isa.org

[2] R. Przysowa Analysis of synchronous blade vibration with the use of linear sine fitting, Journal of KONBiN, 2(30), pp. 5-20, De Gruyter Open (2014).

[3] R. Przysowa "Inductive Sensors for Blade Tip-Timing in Gas Turbines", Test Cell and Controls Instrumentation and EHM Technologies for Military Air, Land and Sea Turbine Engines, MP-AVT-229-10, Rzeszów (2015)

[4] R. Przysowa, P. Gazda "Direct sampling and phase detection of inductive sensor signal", NIDays, Warszawa (2015)

[5] N. Herbring at al. "Chapter 8 - Data Capture, Management and Analysis" in: "Gas Turbine Engine Test Cell Instrumentation", Final Report of Task Group RTG-057, TR-AVT-180, www.cso.nato.int (2014) 
Data management techniques for blade vibration analysis

Techniki zarzadzania danymi w analizie drgań topatek

[6] "Agilis AATAS Software - A complete suite of software for a high cycle fatigue testing of rotating turbo machinery from conception to data reduction" www.agilismeasurementsystems.com (2012)

[7] "Overview of Blade Vibration Monitoring Capabilities", Hood Technology Corporation www.hoodtech.com (2011)

[8] M. Zielinski, G. Ziller "Noncontact Blade Vibration Measurement System for Aero Engine Application". 17th International Symposium on Airbreathing Engines, Paper No. ISABE-2005-1220 Munich (2005)

[9] O. Jousselin "Blade Tip Timing Batch Processor User Guide" DNS147027, Rolls-Royce plc (2011)

[10] "BT Blade Timing Non-Contact Testing System" APEX Turbine Testing Tech-no-lo-gies, apexturbine.com (2014)

[11] "Capacitive Blade Tip Clearance \& Tip Timing measurement system" Fogale nanotech, www.fogale.fr (2012)

[12] "Blade Tip Timing System" Rotadata brochure, Derby (2014).

[13] P. Russhard "BTT MultiTool software" http://emtd-measurement.com/ (2015)

[14] P. Russhard "BTT Data Zeroing Techniques", MFPT and ISA's 59th International Instrumentation Symposium (2013).

[15] P. A. Blume "The LabVIEW style book". Pearson Education (2007).

[16] R. Johansson "Introduction to Scientific Computing in Python", github.com/jrjohansson/scientific-python-lectures (2014)

[17] W. McKinney "Python for data analysis: Data wrangling with Pandas, NumPy, and IPython", O'Reilly Media, Inc.. (2012).

[18] H. Shen "Interactive notebooks: Sharing the code" Nature, 515(7525), 151152 (2014)

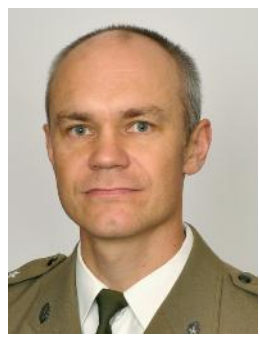

Dr Radostaw Przysowa pracuje jako gtówny specjalista Zakładzie Silników Lotniczych ITWL. Zajmuje się diagnostyka maszyn wirnikowych i pomiarami drgań topatek metoda tiptiming. Posiada znaczące umiejętności programistyczne $w$ zakresie programowania obiektowego, cyfrowego przetwarzania sygnatu $i$ analizy danych.Jest również zaangażowany $w$ zarzadzanie projektami $i$ komercjalizacje wyników badań. Jest absolwentem rządowego programu Top 500 Innovators. (Udziat:50\%).

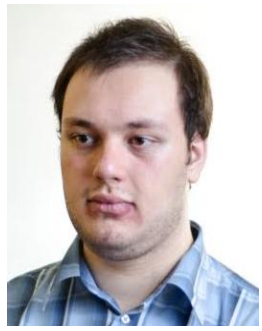

Aleksander Tuzik jest studentem Mechatroniki na Politechnice Wroctawskiej, zaawansowanym programista Pythona $i$ aktywnym czlonkiem zespotu badawczego "Space is More". (Udziat: 50\%). 